\title{
Sáska Géza
}

Eötvös Loránd Tudományegyetem OITK és Neveléstudományi Doktori Iskola

\section{Az egységes és általános iskola megteremtése}

\section{A szovjet hatalmi politika és a magyar nemzetnevelökI}

Szabó Miklós (1935-2000) emlékének

2015-ben a hetven éves állami általános iskola ügye már jószerével érdektelen, a közbeszédben önmagában emlitve csak elvétve jelenik meg. Az okokat illetôen több magyarázat is adódik. A legnyomósabb érv szerint az alsó és felsó tagozatból álló képzési forma harminc éve

tartalmában és szerkezetében megszünt egységesnek lenni, következésképpen általános mivolta is megsemmisült. Voltaképpen új irányt vett a szocialista oktatáspolitika az 1985-ös oktatási törvény

elömunkálataitól kezdve, amely ellentétes volt az elózó, 1945-ben kezdôdó, vagy ha inkább úgy tetszik, inkább 1948-tól tartó idószak

felfogásával. Mindkettó szocialistának tekintette önmagát, a különbség köztük azonban lényeges. A központból vezetett társadalom gondolatát és irányitását felváltotta az alulról szervezódô, önigazgató jellegú társadalom és iskolájának épitése, s ezzel le is mondtak a társadalmi egyenlöség kormányzati eszközökkel való befolyásolásáról (Sáska, 2001, 2002-3). Az alábbiakban arról esik szó, hogy milyen zavaros viszonyok között született meg ez a képzési forma, amelyben meghatározó szerepet játszott szoros szövetségben a nacionalista-faji ideológia alapján álló, javarészt debreceni nemzetnevelók köre és az iskolarendszer átalakitásában a hatalompolitikai eszköz lehetôségét felismeró Kommunista Párt. Az új

szovjet érdekszférában valamennyi ország kommunista pártja ugyanebbe az irányba haladt, akárcsak a földosztás esetében.

\section{A szocialista berendezkedés legitimációja: az általános iskola}

\footnotetext{
A szovjet típusú magyar szocialista (köz)oktatáspolitika kezdetét az 1990 előtti neveléstörténet-írás többnyire az 1945-ben létrehozott általános iskolához köti.

Demokratikus tettnek tekinti az apologetikus irodalom az oktatási rendszer, azaz a képzés tartalmának és szerkezetének, s vele együtt az iskola-szolgáltatáshoz, az iskolai kultúrához való hozzáférés lehetőségének radikális átszabását, a parasztok, a munkások és a majdani vezetök együttnevelése intézményes kereteinek megteremtését, amely felszámolta a felsőfokú továbbtanulás - a vezetővé válás - lehetőségét formálisan elzáró népiskolai és polgári iskolai formát, és kettévágta a nyolc osztályos gimnáziumi képzést.
} 
Valóban megteremtették az oktatáshoz jutás - formális - egyenlőségét. Ezt azonban az ötvenes évek közepére csak brutális és statisztikajavító ${ }^{3}$ tanügy-igazgatási intézkedésekkel $^{4}$, a tanulás-tanítás tárgyi-személyi feltételeinek tudatos rontásával tudták elérni. A rendszeres tananyagcsökkentéssel, illetve a buktatás tilalmával elérték, hogy egy-egy generációnak majdnem a fele tudta befejezni az általános iskolát. ${ }^{5} \mathrm{~A}$ végzettek közül azonban sokan - mintegy harmincezren - nem tanultak tovább (a mezőgazdaságban foglalkoztatottak nélkül $\left.{ }^{6}\right)$, munkába se álltak, otthon maradtak.

Az egyenlőség mértékegysége az iskolába beiratkozott diákok növekvő száma lett, és nem a megszerzett „tudásuk”. A bő első évtizedben a politikai-szakmai norma szerint az egyenlőség megteremtésének számítási alapja a kimaradás és a bukás csökkentéséhez igazított tanulnivaló mértéke, vagyis az iskolában megmaradás foka alapján kiállított bizonyítvány lett. Ez a tudatos politika az iskolarendszerü felnőttoktatásban szembeszökő.?

Az iskolarendszer átszabását az egyenlőséget meghozó szocialista forradalomnak tekintették: a demokrácia ismert hármas jelszavából csak ezt az egyet emelték ki, míg a 'szabadságot' és a 'testvériséget', azaz a szerveződés jogát elvették. Összehasonlításképpen: a nyugat-európai polgári demokratikus országokban az oktatási reformoknak sehol sem volt forradalmi jellege, a tiltakozás és az egyesülés szabadságát sehol sem korlátozták.

Nemes Dezső (1960, 233. o.), a párt keményvonalas ideológusa fogalmazásában a Magyar Kommunista Párt már 1945-ben a társadalmi átalakítás élére állt, ami ekkor már „tartalmazza [...] a szocialista forradalomnak [...] igen lényeges elemeit”. Az általános iskola e forradalom gyümölcse.

Kétségtelen forradalmi tett, parlamenti polgári liberális felfogás szerint azonban egyfajta puccs volt az általános iskola megszervezése, illetve kikényszerítése, mert a reformot nem törvény, hanem rendelet útján indította el az az Ideiglenes Kormány, amelyik köztudottan nem választások révén állt fel, hanem a szovjet csapatok elörenyomulása következtében keletkezett hatalmi ürben és a szovjetek ellenőrzése alatt vette át - mint a neve jelzi: ideiglenesen - az ország irányítását.

A szocialista neveléstudomány vezető képviselői nem érzékelték a demokratikus és a forradalmi viszonyok közötti különbséget, vagy ha mégis, a célok felöl közeledve a puccsot indokoltnak látták. ${ }^{8}$ Ábent Ferenc 1962-ben a kor jellegzetes álláspontját képviselte. A Szovjetunióban kandidált szerző úgy látja, hogy „A közoktatás új rendszere legnagyobbrészt a Magyar Kommunista Pártnak köszönhető [...] a nyolcosztályos, minden gyermek számára kötelező általános iskola életre hívása forradalmi cselekedet volt" (Ábent, 1965, 263. o.9 ${ }^{9}$. Lényegében ugyanezt állítja az ötvenes évek oktatáspolitikájának meghatározó személye, Jóború Magda (1961, 50. o.) is: „Az ideiglenes Kormány a Magyar Kommunista Párt javaslatára 1945. augusztus 16-án rendeletileg kimondta az általános iskola létrehozását." Azaz a puccsot az MKP kényszerítette ki, még ha azt (visszautasíthatatlan) javaslatként fogalmazta is meg Jóború.

A néptanítói iskolázottságú Simon Gyula, oktatáspolitikus, neveléstörténész 1965ben íródott és 1970-ben megismételt sorai szerint az 1945-ös „forradalmi demokratikus átalakulásnak a Magyar Kommunista Párt volt a vezető ereje" (Simon, 1965, 15-18. o.; 1975, 216. o.). Igaza van abban, amit haditudósító stílusban a MKP szerepéről mondott, azonban a forradalom és a demokrácia egymást kizáró fogalmainak együttes használata már későbbi történetírói termék: Kádár János második korszaka ideológia-nélküliségének egyik ismertetőjegye. ${ }^{10}$ 


\section{Az emlékezetből kitörlődött területek}

A forradalmi tettekkel létrehozott szervezetek általános jellegzetessége, hogy létjogosságuk folyamatos igazolást kíván, amely többnyire létrejöttük szükségszerü voltában merül ki. E magyarázat semmit se érne, ha bemutatnák az előzményeket és a lehetséges alternatívákat; éppen ezért kell ezeket elhallgatni, és a feledés homályába küldeni vagy tabusítani.

Úgy látom, hogy - legalább - két elhallgatott mozzanattal számolhatunk az 1945-ös oktatási reformmal kapcsolatban. Az egyik az a tény, hogy a szovjet befolyási övezetben müködő valamennyi kommunista párt egytől egyig az egységes és általános iskola programját képviselte. Ekkora összehangoltság láttán valószínü, hogy a tervet és a politika-technikai módszertant a Szovjetunióban dolgozták ki, az implementációját innen irányították.

Az egyenlőséget ígérő oktatási rendszer kialakításának és az előző rendszer okozta aluliskolázottságból származó hátrányok kompenzálásának (Sáska, 1988) ígérete a hatalomba kerülés tervének az egyik eleme lehetett. A koordinációra utaló jegyekről lejjebb szólunk.

Másodikként pedig azt a kommunista emlékezetpolitikát kell említenem, amellyel az 1945-ös reform elözményeit, valamint taktikai szövetségeseik - a háború elötti, a nyilasokhoz képest moderált jobboldali nemzetnevelök - nézeteit-voltukat elhallgatta, ’45 utáni munkájuk eredményét pedig sajátjaként állította be.

Kezdjük az egységes alapfokú oktatás megteremtéséről szóló - feltételezett - szovjet iniciatívával.

\section{Moszkoviták mindenütt?}

Ahogy a szovjet Vörös Hadsereg haladt Nyugat-Európa felé, nyomukban vagy velük együtt jelentek meg az évek óta az emigrációban élők, és akik a háború alatt többnyire munkaszolgálatosként - a szovjet oldalra átszöktek, majd a katonákkal - nem ritkán egyenruhát viselve - jöttek vissza, mint például Mérei Ferenc. E jól szervezett csoport tagjait és az ideológiájukat osztó, velük együttműködő, korábban ellenzéki szerepben lévő személyeket ${ }^{11}$ nevezte - részben igaztalanul ${ }^{12}$ - a Vallás és Közoktatásügyi Minisztérium 1945-46-os államtitkára, Bassola Zoltán moszkovitáknak.

Valamennyi kelet-európai országban ugyanez történt: mindenütt jelen volt a hatalom megszerzésére szerveződött honi és a katonai előrenyomulással érkező kommunista csoport (Applebaum, 2014). Vélhetően belölük kerültek ki azok, akiknek feladata volt az egységes alapfokú oktatás megteremtése. Közülük sokan voltak olyanok, akik néptanítóként kezdték pályájukat, vagy pedig a tanítóság gimnázium-ellenességére, a gimnáziumi tanársággal, a középosztállyal szembeni irigységgel elegyes ellenszenvére építkeztek. Azokra, akiket vonzott a felemelkedés, a nagyobb tekintély, a magasabb életszínvonal ígérete, s a saját értékeik általánossá tételének vágya és lehetősége. ${ }^{13}$

Kiss Árpádnak ugyanez a tapasztalata a tanítósággal 1947-ben:

„Az általános iskolának ma a tanítóság a legmeggyőződésesebb és legmaróbban hadakozó híve. Elméleti és közösségi szempontokon kívül természetesen az eddigi rendi sérelmek is hajtják egy magasabb minősítés, nagyobb megbecsülés, társadalmi elismerés felé" (Kiss, 1947)

A közösséghez tartozás érzésére és a ressentiment-re bármelyik politikai oldalról ${ }^{14}$, bármikor lehetett politikát építeni. 
Sáska Géza: Az egységes és általános iskola megteremtése

Az ötvenes évek szovjet oktatási miniszterhelyettese elött is ismert volt e tény. Pontosan leírta azt a taktikát, amellyel a kommunista pártok a tanítóságot a hatalom megszerzésének eszközeként felhasználhatják: „a munkásosztály és politikai pártjai már a kapitalizmusban szövetségesüknek tekintették a néptanítót, támogatták az iskola fejlesztéséért ${ }^{15}$ folytatott harcát, és arra törekedtek, hogy bevonják őt a kapitalista társadalom elleni harcba" (Arszenyev, 1965, 29. o.).

A fenti szavak nem elégséges bizonyítéka annak, hogy a kelet-európai kommunista pártok szovjet forgatókönyvből dolgoztak volna. Az intencionalitáson kívül számolni kell funkcionalista magyarázattal is: mindegyik pro-kommunista országban a munkások-parasztok, valamint a középosztály között a megvívandó osztály-harc ígérete általános volt, következésképpen elvileg egymástól függetlenül is rátalálhattak ugyanarra a technikai megoldásra, ennek azonban csekély az esélye. Ami engem illet, a tudatosan felépített koncepció létét tartom valószínűbbnek, hiszen mindegyik országban, ahol a szovjet hadsereg megjelent, valamennyi kommunista párt ugyanazt az irányt mutató programot hirdette meg 1944 és 1948 között, és ugyanazt valósította meg.

Az intenció tényének ${ }^{16}$ elégséges bizonyítéka az, hogy az ötvenes évek legvégén, bő tíz évvel a kelet-európai kommunista hatalomátvétel után, az előbb idézett szovjet politikus-neveléstudós leszögezte:
A szovjet érdekszférába tartozó valamennyi19 európai országban valóban létrehozták az egységes iskolát már a negyvenes években. A nyugati világban ez a fajta egységesség még a hatvanas években sem mutatható ki a Nyolc tókés állam közoktatási rendszerében cimú könyv szerint (Illés, 1967). Az UNESCO 1956. január 9. és 14. között Hamburgban tartott nemzetközi konferenciáján a kapitalista országok neveléstudósai csupán beszéltek arról, hogy milyennek kellene lennie a közoktatás rendszerének. A konferenciakötetet bevezetó tanulmány szavai szerint a polgári demokrácia „egyenlóség elve megköveteli, hogy [...] ne legyen a társadalmi osztályok szerinti megkiülönböztetésen alapuló kettós iskolarendszer" (Faragó, 1959a, 20. o.).

„Az egységes iskola elve megköveteli, hogy a legmagasabb képzettséget minden tanuló elérhesse ${ }^{17}[\ldots]$ Egyik iskola sem lehet 'zsákutca' ${ }^{18}$, amely [a] végzett növendékei számára nem ad lehetőséget a továbbtanulásra. Az egységes iskolának ezek az alapelvei a szocialista országokban már megvalósultak" (Arszenyev, 1965, 29. o.)

A szovjet érdekszférába tartozó valamennyi ${ }^{19}$ európai országban valóban létrehozták az egységes iskolát már a negyvenes években. A nyugati világban ez a fajta egységesség még a hatvanas években sem mutatható ki a Nyolc tőkés állam közoktatási rendszerében ${ }^{20}$ című könyv szerint (Illés, 1967). Az UNESCO 1956. január 9. és 14. között Hamburgban tartott nemzetközi konferenciáján a kapitalista országok neveléstudósai csupán beszéltek arról, hogy milyennek kellene lennie a közoktatás rendszerének. A konferenciakötetet bevezető tanulmány szavai szerint a polgári demokrácia ,egyenlőség elve megköveteli, hogy $[\ldots]$ ne legyen a társadalmi osztályok szerinti megkülönböztetésen alapuló kettős iskolarendszer" (Faragó, 1959a, 20. o.). 
E különbség alapján alapos gyanúval élhetünk, hogy a kelet-európai - benne a magyarországi - egységes általános iskola megteremtése politikai termék, amely a kommunista pártok hatalomra kerülését támogató forgatókönyv egyik fejezete lehetett a háború utáni években.

A fentiekben politikai taktikáról beszéltünk, amely távolról sem azt jelenti, hogy a „zsákutcás" képzési formák megszüntetésének gondolata, esetenként követelése évtizedekkel ezelőtt (vagy később) bárhol meg ne születhetett volna, ahogy a magyarországi Tanácsköztársaság ${ }^{21}$ esetében, vagy később a komprehenzív oktatás bevezetésével Nyugat-Európában meg is történt.

Nem arról beszélünk, hogy az egységes alapfokú oktatás gondolata ne lett volna a levegőben ${ }^{22}$, különösképpen az európai kommunista vagy szociáldemokrata, baloldali gondolkodásúak körében, hanem arról, hogy terveikből - például az 1944-ben született Langevin-Wallon koncepcióból - semmi sem, vagy csak alig-alig valósult meg valami. A fentebb említett hamburgi konferencia megállapította 1956-ban, hogy „az iskolarendszer szerkezete egy fél évszázada lényegében nem módosult" (Faragó, 1959a, 17-18. o.). Kelet-Európában azonban közvetlenül a háború után mindenütt létrehozták az egységes általános iskolát.

Tehát nem is a koncepció a szovjet termék, hanem a megvalósításából faladó politikai haszon learatása, ami a kommunista pártok hatalom-megszerzési módszertanának a része.

Magyarországon a német megszállás előtt már volt hasonló koncepció. A kormányon sohasem lévő Kisgazdapárt oktatási programját a néprajztudós és kommunista szimpatizáns Ortutay Gyula ${ }^{23}$ a kezdeményezésére létrejött Polgári Tagozat tagjaként készítette másokkal együtt 1943 és 1944 között. A program a nemzetnevelés szellemében készült, és az egységes 8 évfolyamos iskola tervét tartalmazta, amely négy éves elemi fokú képzésből és négy éves általános középiskolából állt ${ }^{24}$ (Németh és Pukánszky, 1996). Más koncepcióról nincs tudomásom.

A zsákutcát kiküszöbölő egységes képzés gondolata valóban a levegőben volt, és olykor a kommunista társadalom egyenlőségéig is elment. A háború után a parasztpárti Illyés Gyula felkérésére Németh László $(1945,3$. o.) írta meg a pártok vezetöinek A tanügy rendezése címet viselö munkáját. A tervvel azonban elkésett, hiszen az általános iskolát létrehozó kormányrendelet megjelenése után, 1945 szeptemberében készült el. Számos ponton technikai és elvi szempontból ugyan bírálta a kormányrendeletet, azonban az elvi társadalompolitikai célját nem vitatta. Maga is úgy látta, hogy a tanügyi reform célja „az osztálytalan társadalom megteremtése a most jövő nemzedék müveltségében" (Németh, 1945, 5. o.). Németh 6+6-os rendszert javasolt. Rendszerében a 12 évfolyam az egységes hatosztályos elemire épülő, négyféle irányú (értelmiségi, ipari, mezőgazdasági, adminisztratív) középiskolából tevődött volna össze.

Lássuk most a Szovjetunió érdekszférájába tartozó országokban az egységes általános képzés létrehozásának összehangoltságát mutató jegyeket. ${ }^{25}$ A lényeges momentum nem az új képzés hossza, amelyet a meghaladott iskolarendszer szerkezete eleve meghatározott, hanem az egységes alapfokú képzés kiépítése, vele együtt a „zsákutcás” képzési ág megszüntetése volt.

\section{Az egységes és általános képzés megteremtése a szovjet érdekszférába tartozó kelet-európai országokban}

Csehszlovákiában - ahogy a neveléstudomány szakemberei később megfogalmazták „a reakció ellenállása miatt” a kommunisták csak 1948-ban tudták elfogadtatni az egységes közoktatás szabályozásáról szóló törvényt. A döntő lépést azonban három évvel korábban már megtették: 
„1945 novemberében az általánosan képző iskolák részére új tantervet adtak ki [...] Ennek a feladata volt az is, hogy előkészítse a középiskolák (gimnáziumok, reálgimnáziumok, reáliskolák) alsó négy osztályának a polgári iskolával való összeolvasztását." (Dyma és Kojzar, 1965, 118. o.)

1948 őszétől hozzák létre az általános iskolát, az iskolák államosításával egy időben. „Ez a törvény megszüntette az oktatási rendszer kettősségét és megteremtette az egységes állami iskolát" (Dyma és Kojzar, 1965, 118. o.). Az államosítással teljessé vált az oktatási rendszer egysége.

Lengyelország esete az előbbitől némileg különbözik. A háború utáni oktatáspolitika a német megszállás előtti, az 1932-es reform alapján szerveződő 6+4+2 rendszerű iskolarendszerhez ${ }^{26}$ nyúlt vissza, amelyet a náci megszállás képzés-minimalizálási politikája teljesen elsöpört.

1946-ban hozták létre az egységes hét osztályos általános iskolát a Piłsudski oktatási minisztere, Janusz Jędrzejewicz 1932-es reformjával megteremtett hat osztályos népiskolákból úgy, hogy a korábbi négy osztályos gimnáziumból egy évfolyamot a népiskolához csaptak. 1948-ban azonban kiiktatták a gimnáziumokat, olyképpen, hogy a líceumi képzést egy évvel meghosszabbították. Így jött létre a hétosztályos általános iskola és a négy éves líceum 7+4-es rendszere. Az érettségi megszerzéséhez szükséges képzési idő hossza egy évvel ugyan rövidebb lett, de ,ezáltal megszünt az oktatás több fokozatú jellege, ugyanakkor az ifjúság szélesebb köre számára vált lehetővé, hogy megszerezze az érettségit, és ezáltal a föiskolai tanulmányokhoz való jogot" (Pecherski, 1965, 192. o.). Ez zsákutca nélküli rendszerben a müvelődési egyenlőség megteremtésének módja: rövidül a képzés és megszüntetnek egy szelektáló képzési formát.

Bulgáriában is Csehszlovákiához és Lengyelországhoz sokban hasonló forgatókönyv szerint alakultak az események, noha alapvetően mások voltak a feltételek, de azonosak a politikai körülmények. A háború előtti négy osztályos népiskola és a három éves 'pro-gimnázium' alkotta a képzés alsó szakaszát. A hetedik évfolyam után indult az egyik irányba a „zsákutcás’ ág, a 3 éves reáliskola, amelyet 1944 után szüntettek meg. A felsőbb tanulmányokra felkészítő ág az erősen szelektív, 5 éves gimnáziumi képzés volt (Csakarov és mtsai, 1965, 53. o.). A rendszer zsákutcás ága tíz [(4+3)+3], a felsőfokra vezető ág pedig tizenkét $[(4+3)+5]$ éves volt.

A föként külföldiek által fenntartott 5 éves gimnáziumokat államosították, lényegében bezárták (Georgeoff, 1977). 1950-től kezdték kiépíteni a 11 évfolyamból álló 8 osztályos általános iskola +3 osztályos gimnázium rendszerü egységes iskolát. A háború előtti gimnáziumi ág hosszához képest az egységes képzés egy tanévvel rövidebb lett, éppen úgy, mint Lengyelországban. Az érettségihez Bulgáriában is rövidebb idő alatt és többen juthattak hozzá a fiatalok.

Romániában a zsákutcát a négy osztályos népoktatást követő, három éves szakmai előkészítő tanfolyam jelentette, amelyet a kommunista párt győzelmét követően, az államosítás évében meg is szüntettek, miképpen a nyolc osztályos gimnáziumot is, létrehozva a 7 osztályos egységes állami általános iskolát, amelyre a gimnáziumi képzés három éve épült (Stoian és Gabrea, 1965, 405. o.).

A fentiek alapján távolról sem zárható ki, hogy a kelet-európai kommunisták a béke első napjaitól kezdve egyazon forgatókönyv szerint építették fel (oktatás)politikájukat. Ez esetben közülük a magyarországiak voltak a legsikeresebbek: még a teljes hatalomátvétel előtt elérték az egységes alapfokú oktatás megteremtését és a zsákutcás képzési rendszer felszámolását, ami a többieknek csak a totális hatalomátvétel után - az államosítással egy füst alatt - sikerült. ${ }^{27} \mathrm{Az}$ államosítás Magyarországon már az első pillanatban megkezdödött. ${ }^{28}$ 
A magyarországi sikerben komoly szerepet játszott az is, hogy az irányított demokrácia éveiben a kommunisták sikeresen építhettek a magyar nemzet nevelésében arra a népbarát értelmiségi körre, amely a háború előtti évek fajvédő ideológiájának híveiből s a szociális egyenlőség megteremtésének radikális képviselőiből tevődött össze.

\section{A magyar reform-jobboldal elfeledett hagyatéka}

\section{A tankötelezettség felemelése}

Klebelsberg idején az 1928-ban meghirdetett kormányzati program újabb állomásához érkezett 1940-ben (Pornói, 1995, 322-330. o.). Hóman Bálint előterjesztésében fogadta el a Parlament a 8 osztályos népiskoláról ${ }^{29}$ szóló törvényt. ${ }^{30} \mathrm{Az} 1$. §. szerint a népiskola feladata - többek között -, hogy a növendékeit „további tanulmányokra is képessé tegye". A továbbtanulás útja a gazdasági középiskolák felé vezetett. Ide azonban csak azok jutottak be, akik a népiskola felső tagozatát az átlagot meghaladó eredménnyel végezték el, és sikeres felvételi vizsgát tettek. Felső becsléssel élve legfeljebb a diákok fele jelentkezhetett a felvételi vizsgára.

A jogszabály a politikai szándékot mutatja - más kérdés, hogy ebből mennyi vált valóra. Semmit se von le a 8 osztályos népiskola megteremtéséből, illetve a társadalom tagolódása és az iskolatípus egymáshoz rendelésének politikájából, ha a népiskolák kilencven százaléka továbbra is hatosztályosként müködött 1945-ig (Jóború, 1961, 43. o.). Bármennyire csekély is a végrehajtás hatékonysága, mindez nem érinti az (oktatás)politikai cél kitüzésével együtt járó felelősséget.

A hómani törvény 4. §. (1) szerint:

„az iskolázási kötelezettség a gyermek hatodik életévének betöltésével kezdődik és kilenc iskolai éven át szakadatlanul tart. (2) A gyermek nyolc tanéven át mindennapi népiskolai oktatásban és nevelésben, avagy hat tanéven át mindennapi népiskolai és két tanéven át mindennapi mezőgazdasági népiskolai oktatásban és nevelésben, a kilencedik évben pedig gyakorlati gazdasági oktatásban részesül”.

A $8+1$, illetve a $6+2+1$ rendszerben a tankötelezettség összességében a 15 életévig tartott volna.

Nem lehet tudni, hogy az alulinformáltság, esetleg a törvény végrehajtásának alacsony mértéke ${ }^{31}$ vagy a jogalkotó szándékainak tudatos mellőzése magyarázza, hogy a nyolc osztályos népiskola bevezetését csak a Magyar Kommunista Párt elsőségének és sikeres politikájának állították be. Holott a tankötelezettségröl és az általános iskoláról hozott 1951. évi 15. számú törvényerejü rendeletben foglaltak szerint a tankötelezettek körét az 1940-es népiskolai törvényben foglaltakkal megegyezően állapították meg. ${ }^{32} \mathrm{Az}$ elsőbbségre benyújtott igény alaptalan, a végrehajtás sikere azonban nem. ${ }^{33}$ Az 1930-34-es időszakban a nyolc iskolai osztályt a 14-18 éves korosztály 14,1 százaléka fejezte be, az 1951 és 1955 közötti időszakra vonatkoztatva ugyanez az arány már 64,4 százalék volt (Erdészné, 1957, 692. o.).

Ma a köztudatban az általános iskola létrejötte és a tankötelezettség idejének felemelése összekapcsolódott. Még a hatvanas évek közepén is arról beszéltek, hogy az általános iskolát felállító rendelet ,az iskolakötelezettség időtartalmát a 6-14 éves gyerekek számára 6 évről 8 évre emelte fel" (Ábent, 1965, 263. o.). Az 1976-ban kiadott Pedagógiai Lexikon is arról tudósít, hogy „1945-ben 8 évig tartó mindennapos iskolába járást tették kötelezővé" (Nagy, 1976, 61. o.). Az elsőség vindikálásának meghatározó mozzanata a szocialista berendezkedés legitimálásának lehetett a szempontja, amely az első évtized- 
ben oly erős szükséglet volt, hogy a tényeken is át lehetett lépni ${ }^{34}$, ha azok a tények történetesen nacionalista, fajvédő kormányzati politika termékei. Később, főként a hatvanas évek közepétől, amikorra elfogadható szinten kiépült az általános képzés rendszere, már nem volt politikai jelentősége sem az igazságnak, sem a hazugságnak. Ezt is mindenki elfelejtette.

\section{A Horthy-rendszer belsö ellenzéke}

Létezett egy olyan középosztályi kör, különösen a harmincas évek közepétöl, amely a keresztény nemzeti oktatáspolitikai kurzus Kornis Gyula Kultúra és politika címü könyvében kifejtett ideológiájának (Jóború, 1972, 22-36. o.) zsidóellenes voltát elfogadta, azonban a három részre osztott társadalom mindegyik tagjának más és más képzési formát, oktatási tartalmat adó rendszert már nem, vagy csak részben támogatta.

A rendszerkritika szerint a kulturálisan szakadt társadalom a stabilitást veszélyezteti. A jó társadalomban - felfogásuk szerint - a népi és a magaskultúra egységet kell alkosson, s ezt a dinamikus és szerves kapcsolatot az iskolának, pontosabban a származástól független tehetségek kiemelkedését támogató iskolarendszernek kell kiépítenie.

Kiss Árpád (1943, 25. o.) szerint az az alapvető baj, hogy a magyar társadalom piramisa nem áll ,feldönthetetlen biztonsággal népi alapon, hanem középen megszakad, elveszíti lefelé szilárdságát [...] minden terhelésnél meginog, szomorúan jelezve a [...] népi tartalék elhanyagoltságát és hozzáférhetetlenségét, egész magasabb kultúránk gyökértelenségét". E körben általánosnak mondható, hogy a figyelem fókuszában a magyar nép, a magyar falu, a magyar paraszt állt, amit a középosztállyal szembeni ellenszenv kísért. Az idea az egységes és magyar nemzet megteremtése, amelynek eredményeképpen megszünik a rétegek közötti szakadék, és a lent és a fent közötti kapcsolat organikussá - vagy ha úgy tetszik: funkcionálissá válik.

Anélkül, hogy a téma mélyebb kifejtésére vállalkoznék, itt csak utalni tudok a népi írók tevékenységére, a magyar népélettel hivatásszerüen foglalkozókra, többek között a Györffy István szorgalmazta Magyarságtudományi Intézet tevékenységére. Csupán
Ma a köztudatban az általános iskola létrejötte és a tankötelezettség idejének felemelése összekapcsolódott. Még a hatvanas évek közepén is arról beszéltek, hogy az általános iskolát felállitó rendelet „az iskolakötelezettség idótartalmát a 6-14 éves gyerekek számára 6 évról 8 évre emelte fel" (Ábent, 1965, 263. o.). Az 1976-ban kiadott Pedagógiai Lexikon is arról tudósit, hogy „1945-ben 8 évig tartó mindennapos iskolába járást tették kötelezóvé" (Nagy, 1976, 61. o.). Az elsốség vindikálásának meghatározó mozzanata a szocialista berendezkedés legitimálásának lehetett a szempontja, amely az elsó évtizedben oly erốs szükséglet volt, hogy a tényeken is át lehetett lépni, ha azok a tények történetesen nacionalista, fajvédó kor-

mányzati politika termékei. Késóbb, fóként a hatvanas évek közepétól, amikorra elfogadható szinten kiépült az általános képzés rendszere, már nem volt politikai jelentốsége sem az igazságnak, sem a hazugságnak. Ezt is mindenki elfelejtette. 
példaként hozom fel az Intézet kiadásában 1941-ben megjelent Úr és paraszt a magyar élet egységében címü konferencia-könyvet, amelynek szerzői közül többen az 1945-ös fordulat után a politikai élet aktív szereplői lettek. A könyv előszava szerint „,valamennyi előadó megállapítja, hogy a magyar müveltség alsó és felső rétegei állandó körforgásban élnek; majd alulról érkezik a tápláló nedv, majd meg felülröl a termékenyítő ösztönzés, sőt a két müveltség egységbe olvad, a magyar nemzeti müveltség nagy egységébe" (Eckhardt, 1941).

Mindebben az a fontos szemléleti elem, hogy egységes és általános magyar nemzeti múveltség - azaz nem német és nem zsidó. A társadalomnak magyarnak kell lennie. Nos, ebből a nem-pedagógus szerzői körből négyen (Keresztury, Kodály, Mendöl, Ortutay) szerepelnek az 1945-ben az Országos Köznevelési Tanács által kiadott programadó Demokrácia és Köznevelés kiadványban (Sik, 1945). Ugyanebben az újrakezdést szimbolizáló 1945-ös kötetben jelentek meg a háború előtti közéletben a magyar népi-paraszti tehetséget - a középosztály rovására - vezetői helyzetben szívesen látó, új műveltségeszmét ajánló személyek, a fentebb említetteken kívül Kiss Árpád, Kovács Máté, Simon László ${ }^{35}$, Szombatfalvy Gyula, Veres Péter. Rajtuk kívül a kötetben olyanok is szerepelnek, akik a végleg elpusztult állam politikai ellenfelei, üldözöttei, mellőzöttei, később a szocialista berendezkedés vezetői voltak, mint a hazai vagy a Szovjetunióból érkezett kommunista Andics Erzsébet és Rudas László, valamint a magyarországi kripto-kommunista Molnár Erik. Hirtelenjében azonos platformon találjuk az üldözötteket és egykori üldözőiket. Valamennyien az újrakezdés hívei voltak, noha másképp képzelték el a jövőt, aminek csupán az egyik eleme, hogy 1948 után a szerepek felcserélődtek: az üldözőkből üldözöttek lettek. Mindebből itt számunkra az a fontos, hogy láthassuk: a két korszak között a jobboldalon volt személyi, ideológiai átmenet a pedagógia, a közoktatás területén.

\section{A fajszeretet és a szocializmus}

Az általános iskola létrejöttében meghatározó politikai és technikai szerepet játszó Kiss Árpád és Kovács Máté már a háború előtt az Országos Közoktatási Tanács tagjai voltak, pedagógiai felfogásuk akkor a magyarságvédelmi, nemzetnevelési alapon állt. Önálló magyar pedagógiát, nevelést szorgalmazott az 1944-45 előtti Kiss Árpád, olyat, amely nem idegen eredetü. Azt írja a Magyarságtudomány és Nemzetnevelés címü - Kovács Mátéval közösen szerkesztett - kötetben:

„Nevelésünk [...] a maga egészében szerves folytatása az első világháború előtt kiépült, idegen minták szerint, idegen tanulságok felhasználásával alakított nagyszabású iskolarendszernek, melyben a nevelés intézményeit, a nevelési eljárások formális törvényeit, a tanterv szerkezetét nézve sok sajátosan magyart vagy magyarost nem igen találunk" (Kiss, 1944, 49. o.).

Kovács Máté ugyanezt állítja a politikai fordulat után, 1945-ben is. Szerinte a köznevelés

„legszembetünő hiánya és hibája, hogy nem egyetemes, nem a magyarság egészét szolgálja, hanem a tanulók kiválasztásában csupán az értelmiségi utánpótlást, azaz a letünt uralmi rendszer érdekeit ${ }^{36}[\ldots]$ szolgálja. Ráadásul sok tekintetben idegen mintát követ" (Kovács, 1945, 107. o.). 
Ezt a gondolatot megismétli az Országos Köznevelési Tanács számára 1945-ben készült sokszorosított előterjesztésében is. Úgy látja a demokrácia első esztendejében, hogy a meghaladott nevelöképzésböl hiányzott a

„magyar lelkület ${ }^{37}$ korszerü színvonalon való tanulmányozása. A magyar lelkület sajátos igényeinek és törvényszerüségeinek nemismerése, népi kultúránk nevelő hatásának elhanyagolása, idegen, fóként német minták másolgatása, az idegen, főként német kultúra nevelő hatásának túlzott szerephez juttatása...” (Kovács, 1983, 177-178. о.)

A Kiss Árpád és Kovács Máté szerkesztette, a háború vége előtt, Magyarságtudomány és Nemzetnevelés címen kiadott könyvben jelent meg a kor egyik számon tartott pszichológusának és neveléstudósának, Boda Istvánnak ${ }^{38}$, ekkor a kolozsvári egyetem neveléstani tanszékvezetőjének antiszemita cikke A magyar lélek alapformái és természetes fejlödéslehetőségei címmel (Boda, 1944, 21-45. o.). Megítélése szerint

„hazánk földjén maradva is könnyen kimutatható pl. a magyar és a zsidó származású földbirtokosok pszichés másfélesége [...] A magam vizsgálatainak köréből nyilatkozhatom pl. az ügyvédi és bírói beállítódásformák bizonyos különbségeiröl a magyar és a zsidó származású ügyvédeknél és bíráknál”39 (Boda, 1944, 29. o.).

A magyarságvédelem apostola - Kiss Árpád szavai szerint - Karácsony Sándor, aki a háború után Révai József felkérésére maga is kiterjedt közéleti szerepet vállalt. ${ }^{40}$

„Tartozunk is a magyar nevelés példával buzdító apostolának, Karácsony Sándornak azzal, hogy a magyarságra törekvő nevelésnek legalább egy részét hozzá vezessük vissza. Egyik legutóbbi meghatározása a következő: »Nevelésünk tartalma annyiban új, amennyiben magyar. Mennél magyarabb, annál újabb - írja. - Azt, hogy mi a magyar, szó szerint nem is tudjuk, legfeljebb sejtjük. Ezért nevelésünk tartalmi magyarsága egészen újkeletü, modern követelmény«" (Kiss és Kovács, 1944, 52. o.)

A nacionalizmusra épülő neveléstudomány mint a modernség jegye igencsak hatékony ideológia lehetett.

A nemzetnevelés eleme a parasztok mobilitásának bürokratikus támogatása. A Magyar Néprajzi Társaság Társadalomtudományi Szakosztályának Társadalomtudomány címü folyóiratában Szombatfalvy György, a Társaság ügyvezető elnöke, s emellett a VKM tisztviselője, majd a háború után az általános iskola területén a VKM tanügyi fötanácsosa, kimutatta, hogy a magyar vezetőréteg előképzésében meghatározó szerepet játszó gimnáziumok nem merítenek a paraszti rétegből. Minthogy a gimnáziumok városokban müködnek, a távolabb lakók nem érhetik el. Míg az iskolától távoli helyeken ezer kereső közül átlagosan csak heten gimnazisták, addig Budapesten és környékén, valamint a városokban általában négyszer, ötször annyian vannak ilyenek. Mindennek következtében jelentős előnyt élvez a városi hivatalnoki polgári réteg az „őstermelö réteggel szemben" (Szombatfalvy, 1941a, 1941b).

A kormány 1941-ben Állami Tehetségvédelmi Alapot létesített Szombatfalvy György kezdeményezésére (Martinkó, 2006). A VKM 57436/1941. sz. rendelete a miniszter irányítása alatt álló gimnáziumi tanulók szüleit különböző, a Horthy Miklós Ösztöndíjalapra befolyó járulékok fizetésére kötelezte ,a tehetséges falusi szegény tanulók gimnáziumi tanulásának előmozdítására", és ugyanezen logika alapján emelték fel a polgári iskolai tandíjat is (Pornói, 2011, 125. o.). A szegény tanulók továbbtanulásának finanszírozá- 
sát technikailag a középosztály terhére, a tandíjak emelésével tervezték megoldani. ${ }^{41}$ A középosztály-ellenesség ugyanaz, mint a nyolc osztályos általános iskola létrehozásánál - de a léptéke távolról sem akkora.

A magyar tehetség kibontakoztatása előtt meredő faji akadályok lebontása is a pedagógiai gondolkodás és politika eleme. Hóman miniszteri hatáskörben rendelte el a hat százalékos zsidó-kvóta alkalmazását a középiskolák első évfolyamára történő felvételeknél 1939-ben. Abban a négy budapesti közösségi középiskolában, ahová zsidók nagyobb arányú felvételét engedélyezte, az iskola épületében egyfajta gettót állítatott fel: elöírta a zsidó és nem zsidó tanulók térbeni elkülönítését (Ungváry, 2016), egy osztályba nem járhattak. E politika irányából semmit se vesz el, hogy a jogszabályt „nem hajtották szigorúan végre" (Ujváry, 2016, 57. o.).

Tudjuk, hogy ennek a politikának az egyik nagyhatású ideológusa Németh László volt. A Társadalomtudomány címủ lap Figyelö rovatában 1939-ben Szombatfalvy György dicsérő sorokat írt Németh László Kisebbségben címü művéről. Szerinte Németh ebben a könyvében adja meg a választ a disszimiláció kérdésére. „Nincs még egy foltja Európának - idézi Szombatfalvy $(1939,105$. o.) -, melyen fajszeretet és szociálizmus ennyire egy, mint nálunk, ahol a szegénységnek a négyötöde a magyar és az elnyomóknak négyötöde nem az" ${ }^{42}$ Az elnyomók és az elnyomottak helyzetét a faj mássága okozza a harmadik utas ideológia és pedagógia magyarázata szerint, s innen nem kell nagy ugrás, hogy a kommunista társadalom-magyarázatban a kizsákmányoló uralkodó osztályban is az idegent találja majd meg a népbarát logika, akinek a pusztulását, kitelepítését, vagyonának elrablását vagy államosítását nem is bánja.

A fajszeretet és a szocializmus eszménye Kiss Árpádtól sem idegen, mintája Hitler. Helyeslően idézi a Führert: ,,az a nép [...] amelyiknek egyik fele nyomorúságos és gondoktól gyötört, vagy éppen elsatnyult, olyan rossz benyomást kelt, hogy láttára senki se érezhet büszkeséget” (Kiss, 1943, 24. o.). És itt következik a német nemzetiszocialista ideológiával való azonosulás: „,ez az ítélet senkiben sem kelthet mélyebb gondolatokat, mint bennünk, magyarokban" (Kiss, 1943, 24. o.). Az elismerés mellett azonban ott van a németektől - a nemzetiszocializmustól - távolságot tartó félelem is. Noha a német nevelés számtalan kezdeményezést sugallt már - mondja - a hatalmas nép szomszédságában a magyarságnak is, éppen ezért „létének magyar vonásait mindig [tehát 1941-ben is - S. G.] féltenie kellett" (Kiss, 1943, 59. o.).

Kiss Árpád antiszemitizmusának és németellenességének oka a magyarság térvesztése, a parasztság megromlásának a magyarázatát bennük látja, s erre történeti-szociológiai magyarázatot kínál:

„[A] XIX. század második felében gazdaságilag hirtelen fellendült országunk [...] jövedelmező foglalkozásait a zsidóság és az élelmesebb elmagyarosodott nemzetiségek [vélhetően a németek - S. G.] már régen megszállták, mikor a növekvő létszámú magyarság elhelyezkedést próbált találni. [...] A friss vér, az egészségesen tisztító levegő romlott meg a beszivárgás ideje alatt: az alul oly szépen virágzó erények adtak helyet egy mohó vágynak, hogy a legrövidebb idő alatt bekövetkezzék az uralmon lévőkhöz való teljes hasonlóság..." (Kiss, 1943, 28. o.).

A szép metaforák fejezik ki a bevándorlók okozta veszedelmet. Az idegenellenesség a fajvédelem ideológiájának jellegzetes eleme.

Az idegenellenességéből azonban nem következett a teljes és tökéletes faji tisztaság megteremtésének szándéka: Kiss kételkedik abban, hogy hasznos volna, ha a „,vezető fajnak”, a magyarnak előjogai lennének a „közösségi élet minden területén” (Kiss, 1943, 77. o.). Ha jól értem: gazdasági vonzatait nem számítva, nem fenntartás nélküli híve sem a zsidótörvényeknek, sem a németek majdani kitelepítésének. 
A kor totalitárius és autoriter államaiban általános felfogás szerint (ld. többek között Hitler $^{43}$, Hóman $^{44}$ ) a jó állam alapja a származástól, a családi körülményektől függetlenül megszerezhető 'megfelelő' tudás és a természet adta 'jó' képesség. A biológiai adottságként felfogott és felismert 'tehetség' az alapja és feltétele annak, hogy a legalacsonyabb társadalmi rétegböl a legmagasabbra lehessen jutni.

A tehetségkeresés, képzés elsősorban az elnyomott parasztok számára nyújtja a felemelkedés lehetőségét, azoknak, akik a faj- legyen az német, magyar vagy e nézetrendszer szerint bármelyik államé - ősi tulajdonságait a legtisztábban megőrizték. A tehetségmentő politika megvalósítására lehetőség nyílott a zsidó törvények és az ország határainak átrajzolása után, ahogy olvashatjuk a Protestáns Tanügyi Szemlében, „,mert nemcsak jeles közigazgatási emberek képzésére van szükség, hanem a zsidó törvények folytán elhagyott, és még gazdátlanná váló helyek benépesítésére is" (Csanády, 1940, 241. o.).

Kiss Árpád nem híve a negyvenes évekbeli oktatási rendszer logikájának, alighanem szakmai-technikai tekintetben közelebb állt a két évvel később bevezetett általános iskola kínálta megoldáshoz, amelynek létrehozásában neki is, Kovács Máténak is tetemes szerepe volt. Ủgy látja, hogy a vezérelvet szolgáló szelekciónak, azaz a kiválasztásnak a „tanuló szempontjából [...] a végérvényesen elutasító döntésnek a mainál későbbre való halasztása” fontos, mert „a tanuló tízedik évében felnyíló legyező - amely innentől kezdve külön ágakban halad - idő elött vezetheti a tanulót egyik vagy a másik irányba" (Kiss, 1943, 33. o.). Ez a bírálat nyilvánvalóan érinti a 8 osztályos népiskola koncepcióját is.

A harmincas évei közepe felé járó szerző az iskolák szervezetének és szellemének egységesítésének - azaz a tanügyigazgatásnak - az uralmát, fontosságát hangsúlyozza, mindazért, mert ilyen berendezkedés mellett „az iskolában folyó nevelés biztosíthatja helyes kiválasztás után a felhozott értékek megmaradását” (Kiss, 1943, 33. o.). Technikai-szakmai tekintetben 1945 után valóra válhattak szavai: a centralizáció, a magasabb életkorra tolódó formális szelekció megvalósult, azonban a „helyes kiválasztás” és a „felhozott értékek” tartalma-jelentése a felfogásával ellentétes értelmezést kapott az osztályharchoz kötött elitcsere éveiben.

\section{A fajszeretet és a demokrácia}

A két háború között időszakban a nemzetnevelés politikai programjával sokan azonosultak a pedagógia vezető képviselői közül. Szemükben stratégiai jelentőségü volt a felnövekvő generációk és a később felnőttek hazafias nevelése, amelyhez képest az oktatás - a tudás és a racionalitás kozmopolita jellege miatt - második sorba szorult. Ezzel magyarázható, hogy a társadalmi tudat formálásának a hívei már a háború vége elött többször is meg akarták változtatni az Országos Közoktatási Tanács nevét, amelyet akkor nem, de 1945 után már sikerült nekik elérni. Ekkor született az Országos Köznevelési Tanács ${ }^{45}$, amelyben a nemzetnevelés új tartalmat kapott. Ahogy Veres Péter $(1945,7$. o.) kifejtette, a teendő a régi rendszer lebontása mellett „demokráciára nevelni és magyarságra nevelni”. A magyarság jelentése megváltozott. A háború után - amikor Európa-szerte etnikai tisztogatás folyt, Magyarországról éppen a németek és szlovákok ki-, és Szlovákiából és Romániából a magyarok betelepítése zajlott - a demokratikus magyarság felnevelése lesz az új nevelési eszmény, amely abban különbözik a korábbi időszak felfogásától, hogy a magyarságot nem fajbiológiai, fajpszichológiai tudományos tételekből, hanem a magyar gyerekek - pedológiai indíttatásból - ösztönös viselkedéséböl vezeti le (Sáska, 2011).

Az Országos Köznevelési Tanács az 1945/46-os tanévre kiadott Kiegészitő utasitásában olvasható ${ }^{46}$, „minthogy magyarságunk törvényei, emberségünk sajátosan magyar 
jegyei még nem teljességükben ismertek, használják fel a nevelők ${ }^{47}$ a rájuk bízott ifjúság spontán és gátlásnélküli megnyilatkozásait ${ }^{48}$, azoknak a finom megkülönböztetéseknek a rögzítésére, amelyek a magyar lélekre szabott nevelés lassú megvalósulása érdekében szükségesek" (OKNT, 1945, 9.1).

Az éppen zajló fajtisztaságot eredményező etnikai tisztogatás - a németek kitelepíté$\mathrm{se}^{49}$ - feltehetőleg oszlatta a magyar lélek nevelésének hatékonysága feletti aggodalmak egy részét.

\section{A fajszeretet-demokrácia és a gyermektanulmányozás}

A magyar lélekre szabott nevelés gondolata ugyanazon az alapon állt, mint húsz évvel korábban a tanítói képzettségű volt kormányfö, Huszár Károly, aki a Magyar Gyermektanulmányi Társaság és Gyakorlati Lélektani Társaság 1926-ben megszervezett gyermekrajz-kiállításának megnyitó beszédében a gyermekrajzok láttán arról beszélt, hogy a „magyar őserő feltörése és felcsillogása tünik itt elénk. Ami előttünk áll, bizonyítéka annak, hogy a magyar élet gyökértalajában egészséges energiák szunnyadnak, s igyekeznek felkészülni, hogy a múltban megszerzett kulturális erőt a jövőnknek átadhassák" (idézi Ozorai és Bálint, 1927, 17. o.).

Ugyanezen biológiai eredetü, természet-alapú gondolat talaján áll Nagy László (1930, 81. o.) is, aki szakmásítva mondja ugyanazt: „Tehetség az összes biológiai és pszichológiai erők magasabb fejlettségi foka és alkotásokra törekvő iránya". Huszár nemzeti, faji mozzanatot lát a gyermeki rajzokban, Nagy a természeti adottságok kibontakoztatását. A két álláspont eszmei alapja ugyanaz.

A magyar gyermek egyediségének empirikus bizonyítékainak feltárására többek között Ballai Károly, a Gyermektanulmányi Múzeum igazgatója is vállalkozott. 1929ben kiadott könyvében a magyar faj gyermekeinek koponyaméretei alapján vont le következtetéseket (Ballai, 1929). Az ötödik fejezetben például a magyar és az idegen gyermek megkülönböztető jegyeiről értekezett pozitivista munkájában.

A gyermektanulmányozásnak azonban van a faji szempontokat mellőző ága is, amelynek képviselői a gyermekben a jövő osztálynélküli társadalmának fiatal tagját látják. Noha mindkét irányzat képviselői a társadalom megjavítása érdekében alkalmaznák a gyermektanulmányozás felfelezéseit, azonban a felnőttek világára vonatkozó céljaik, a 'jó' társadalomról alkotott ideológiájuk gyökeresen eltér egymástól, míg közös bennük az alakítható 'gyermek', pontosabban a gyermekben rejlő politikai potenciál felismerése. ${ }^{50}$

Az oktatáspolitikai közbeszédben 1945-ben találkozott a Mérei Ferenc képviselte gyermektanulmányi szemlélet és a fajvédelemi alapú alkalmazott pszichológia.

Visszatekintve úgy tűnik, hogy a Horthy-rendszer autoriter rendjét elfogadó és a totalitárius rend felé igyekvő pedagógusok és pszichológusok együttmüködésének közös vonása a polgári liberális demokrácia iránti mérsékelt vonzódás.

\section{Hogyan? Miért?}

Randolph L. Braham $(2015,229$. o.) szerint tudatos kommunista politika hozta létre ezt a különös frigyet:

„Kommunistákat és szövetségeseiket [...] az államhatalom megszerzését célzó politikai küzdelem foglalta el. Hogy az antiszemitizmus által változatlanul áthatott keresztény emberek [...] támogatását megszerezzék, a baloldali vezetők az elsők között alkalmazták az 'általánosítás' módszerét, és intéztek támadást a holokauszt ténye és egyedisége ellen" 
Ez a magyarországi politika sem helyi innováció, a Sztálin irányította taktikát valamenynyi kommunista párt követte (Applebaum, 2014).

Rákosi Mátyást 1945-ben, 1946-ban éppen ezért aggasztotta, hogy az antifasiszta perek ,túlságosan is azokra összpontosulnak, akik valamit müveltek a zsidókkal” ( $A p p$ lebaum, 2014, 174-175. o.). Rákosi nem véletlenül füszerezte parlamenti beszédét antiszemita megjegyzésekkel (uo.), nyilván azon okból, amire Braham rámutatott.

A kommunisták szövetségese e tekintetben a nemzeti-faji, népi talajon álló írókat és értelmiségieket összefogó Nemzeti Parasztpárt volt. Pontosabban a Darvas József - a későbbi miniszter - nevével jellemezhető vonal volt együttműködésre hajlamos (Standeisky, 2007; Papp, 2012). Szabó Miklós (2014) szerint tőlük ered a nemzeti színű szocializmus gyakorlata.

1958-ból visszatekintve, az MSZMP Kulturális munkaközössége helyeselte, hogy 1945 őszén a MKP „nem élezte ki az ideológiai ellentéteket, sőt megvédte a »népi« írókat a szociáldemokrata jobboldal és a polgári demokraták oldaláról jövő támadásokkal szemben (Zsolt, Faragó László ${ }^{51}$ stb. vonalával, általában a »Haladás « ${ }^{52}$ vonalával szemben)” (Vass és Ságvári, 1973a, 224. o.). Ez a taktika vélhetően érvényesült a nemzetnevelök esetében is.

Azt már tudjuk, hogy a magyarországi jobb- és baloldal szövetsége az 1948-as kommunista hatalomátvételig tartott, amikor a baloldal felszámolt minden korábbi szövetséget és valamennyi kooperáción alapuló intézményt. ${ }^{53} \mathrm{Az}$ is ismert, hogy 1950-ig kizárták a közéletből, a tanügyigazgatásból - néhány kivétellel - mindazokat, akik az 1945 elötti években a fajvédő politika népbarát hívei és pedagógiai képviselői voltak, s akarva-akaratlanul hozzájárultak a kommunista oktatáspolitika sikeréhez, benne az egységes nyolc osztályos általános iskola bevezetésével, a szabadoktatás kiépítésével. Ugyanerre a sorsa jutottak a nyugat-orientált kommunisták is. (Az ismertebbek Kiss Árpád, Karácsony Sándor, Mérei Ferenc.)

Történetük a későbbi években előbb tabusodott, talán éppen ez is kellett néhányuk későbbi rehabilitációjához, amely a rendszerváltás után glorifikációba torkollott. ${ }^{54}$ Ehhez az is kellett, hogy 1945 után a fajvédő pedagógusok a nacionalizmusukból teljesen kihagyták a fajvédő szólamot: nem volt nehéz a Moszkva felé tájékozódó kommunista pedagógia politikai alternatívájaként megjelenni és ebben a formában továbbélni az emlékezetben. Már az Országos Neveléstudományi Intézetben dolgozó Faragó László és Kiss Árpád (1949) Az új nevelés kérdései közös könyvének címében az ‘új’ jelentése eltér az oktatáspolitika kommunista irányvonalától; kettőjük, valamint Mérei pedológiai elhajlása nem is maradt büntetlenül. Az MDP KV 1950-es párthatározata meg is tette, kijelentvén, hogy a „burzsoá pedagógia melegágya” és az ellenséges tevékenység egyik góca éppen az Országos Neveléstudományi Intézet (Knausz, 1986, 1994, 46. o.).

Velük együtt mindenkit eltávolították - többek között korai nyugdíjaztatással ${ }^{55}$ - a felsőoktatásból, a Magyar Tudományos Akadémiából, azokat is, akik bár távol tartották magukat a szakma-politikai közélettől, azonban nézeteiket a marxizmussal ellenségesnek és ezért károsnak tekintették. Prohászka Lajos nevével jellemezhető ez a csoport. Helyüket az új rendszer feltétlen - és fiatal ${ }^{56}$ - hívei foglalták el, akit tudatosan, vagy helyzetükből fakadóan automatikusan a feledésbe küldték elödeiket (Németh és mtsai, 2016; Sáska, 2015).

Legalább még két dolog játszott szerepet a parasztgyerek-párti, nemzeti fajvédő pedagógusok tetteinek az elfelejtésében. Az egyik a jól ismert 'összemosás' politikájának következménye. Valamennyi 1945 utáni nem-kommunista irányzatot és tagjait összességében - korábbi nézeteiktől és tetteiktöl függetlenül - 'polgári humanistának', azaz nem-kommunistaként, nem-marxistaként kezelték. Hozzájuk csapták még a kiátkozott meggyőződéses baloldali gondolkodásúakat is. Így egy kalap alá került többek között Szentgyörgyi Albert, Szombatfalvy György, Várkonyi Hildebrand, Prohászka Lajos, 
Mérei Ferenc, a reformpedagógus protestáns lelkész, Nánay Béla, a katolikus pap Árpás Ferenc, a pécsi Barankay Lajos, az 1944-ben kiadott $A$ népi gondolat müvelödésünkben a nemzet ébredéséig címü könyv szerzője, ahogyan a kor vezető pedagógiai ideológusa, Szarka József az erkölcsi nevelés elméletének ${ }^{57}$ fejlődése kapcsán írt tanulmányából kiderül (Szarka, 1962, 8-30. o.). ${ }^{58}$

A másik ok az, hogy az ötvenes évektől sohasem jutottak nyilvánossághoz a Magyarországon maradtak. Innentől számolva csak a baloldal megosztottsága, a 'dogmatikus' (rákosista) és a 'revizionista' (Nagy Imre-i) (Vass és Ságvári, 1973b, 33. o.) politika Kádár által 1957-ben meghirdetett együttes elutasítása volt a politika fö témája. ${ }^{59}$

\section{Végezetül}

Az ötvenes évek közepére-végére végképp megsemmisült az a háború előtti, faji szempontok szerint érvelő, szociálisan érzékeny, jobboldali oktatáspolitikát, pedagógiát képviselő csoport, amelyik az autoriter Horthy-rendszer keretei között népbarátként, akár a középosztály ellenére, a parasztság iskoláztatásának ügyét képviselte. Szerepüket

Az ötvenes évek közepére-végére végképp megsemmisült az a háború elötti, faji szempontok. szerint érveló, szociálisan érzékeny, jobboldali oktatáspolitikát, pedagógiát képviseló csoport, amelyik az autoriter Horthyrendszer keretei között népbarátként, akár a középosztály ellenére, a parasztság iskoláztatásának ügyét képviselte. Szerepüket majd a hatvanas években az anti-sztálinista, mélyen egyenlóségelvú urbánus baloldal veszi át, számon kérve a szocialista államon a munkások és a parasztok iskolázottságban mutatkozó hátrányát, a növekvô társadalmi különbségeket. majd a hatvanas években az anti-sztálinista, mélyen egyenlőségelvü urbánus baloldal veszi át, számon kérve a szocialista államon a munkások és a parasztok iskolázottságban mutatkozó hátrányát, a növekvő társadalmi különbségeket.

Kádár János lassú megbékélési politikát folytatott a kommunista rendszer első évtizedében az osztályharcban megsértett-megkínzott középosztály kiengesztelésére a származás nyilvántartásának eltörlésével, a tagozatok (szakszerűen: a speciális tantervü osztályok) megnyitásával, a fakultáció bevezetésével, a tanulmányi teljesítményre épülő közép- és felsőfokú felvételi rendszer reneszánszával. Addig-addig, míg a korszak legvégén már mindent odaadtak, amit korábban, az egyenlőség érdekében elvettek, a hat- és a nyolcosztályos gimnáziumoktól az alternatív pedagógiáig. Minden hatalomgyakorlási eszközt eldobtak, a tanfelügyelettől az igazgatók kinevezési jogáig.

Mindegyik döntést a szocialista demokrácia térnyeréseként tálalták, amelyek valójában a szovjet típusú szocializmus elhúzódó és elmélyülő agóniájának a jelei voltak: az egyenlőtlenség növekedett, azonban a polgári demokratikus szabadság gyakorlását a Szovjetunió összeomlásáig továbbra is az állami, a pártigaztatás és a belügyi ellenőrzés tette lehetetlenné.

Mindez azonban már egy másik, a rendszerváltás utáni, a polgári demokrácia éveire is kiható történet, amelyben eljött a szabadság, és vele nőtt az egyenlötlenség is. A régi fajta nemzeti-faji alapra építkező antiszemita politikusok, noha megjelentek (Szabó, 1995), 
azonban hozzájuk kötődő nemzetnevelő pedagógus ideológusok-politikusok talán nem is voltak.

Új korszakot nyitott az 1993-as, a Közoktatásról szóló LXXIX. törvényt 2011-ben felváltó Nemzeti Köznevelési Törvény, amely már a nevében is legitimálta a háború előtti, valamint a közvetlenül a háború utáni évek nemzetnevelés-pedagógiáját és vele együtt a kudarcos oktatáspolitikát.

\section{Köszönetnyilvánítás}

Itt köszönöm meg Baska Gabriella, Donáth Péter, Csákó Mihály, Kovács András, Laki Mihály, Lukács Péter, Nagy Péter Tibor, Polónyi István, Setényi János, valamint Szabó Zoltán András észrevételeit és javaslatait, nélkülük az olvasó sokkal nehezebben boldogult volna e szöveggel.

\section{Jegyzetek}

${ }^{1}$ E tanulmány az OTKA K100496 számú kutatás keretében készült, amelynek terjedelmesebb változata Németh András és Garai Imre szerkesztésében megjelenő könyvben Az oktatási rendszer reformja a negyvenes években és a kommunista identitáspolitika címmel fog megjelenni.

${ }^{2}$ A másik magyarázat a tömegoktatás kiterjedéséből adódik: ma egy generáció megközelítőleg hetven százaléka érettségizik, azaz az életutat meghatározó formális döntés a 14. életévröl még magasabbra került. Ebből fakadóan az általános iskola igen kevés hihető ígéretet tehet diákjainak jövőjéről. A harmadik magyarázat az állami egységes és áltanos iskola létrejöttéhez, illetve legitimációjához kötődik. Az egy generációval korábbi szocialista rendszer bukásával együtt megszűnt az az intézményrendszer, amelyik folyamatosan ápolta e képzési forma vívmány mivoltát, képviselői kiöregedtek, követőik nem akadtak.

${ }^{3} \mathrm{Az}$ iskola igazgatója hivatalból köteles volt beírni azokat a gyereket is, akiket a szüleik felszólításuk ellenére sem írattak be, a 1951. évi 15. sz. tvr. 6. §-a szerint.

${ }^{4}$ Az ötvenes évek elején az osztálytermek 44,6 százalékát váltott rendszerben használták (Erdészné, 1957, 694. o.).

${ }^{5}$ Az 1947/48-ban beiratkozott tanulók 51,7 százaléka nem lett nyolcadikos az 1955/56-os tanévben. A 6 éves korú generáció 3,3 százaléka be sem iratkozott az iskolába 1952-ben. Ugyanakkor az általános iskolában a túlkoros tanulók (az évismétlők) aránya 1952/53-ban 24,3, 1956/57-ben 18,0 százalék volt. Az 1955/1956-ban végző általános iskolai diákok tanulmányi idejük alatt „13 fontosabb felsőtagozatos tantárgyat vizsgálva - 14 tanterv- és 16 tankönyvmódosítást hajtottak végre" (Erdészné, 1957, 690-693. о.).

${ }^{6}$ A gyermekmunkára alapvetően a mezőgazdaságban volt szükség. Az állami vállalatok többnyire betartották az idézet tvr. 8. §-át, tanköteles gyereket szorgal- mi idő alatt alkalmi vagy rendszeres munkára nem alkalmaztak.

${ }^{7} \mathrm{Az}$ analfabetizmus ,elleni küzdelem” is politikai termék. Az 1949. évi népszámlálás adatai szerint a 20-29 évesek között szinte nem is volt analfabéta ( 1,8 százalék). A 6 évesnél idősebb népesség körében csupán 5 százalék nem tudott írni, olvasni - kézenfekvő, hogy közülük a legnagyobb arányban a 6 évesek (64,2 százalékuk). A 80 évesek és idősebbeknek pedig 21,7 százaléka volt analfabéta $(K S H$, 1950, 41. o.). A 12 évesnél idősebb népesség 68,6 százalékának volt 1949-ben hat osztálynyi végzettsége (KSH, 1950, 37. o.).

${ }^{8} \mathrm{Az}$ általános iskola történetét pedagógus kultúrájú személyek írták, akik fóként e nézőpontból tekintettek az eseményekre. Politológiai szempontú elemzés nem született, ha az apologetikát nem vesszük tekintetbe. Ezzel magyarázható, hogy a 'jó szakmai törekvések és a rossz politikai döntések' logikája szerint íródott a történet (ld. pl. Horváth, 1978; Kardos, 2007).

${ }^{9}$ Az idézet első forrása: Das schulwesen sozialisticher lander In Europa. Volk and Wissen Volkgseigener Verlag, Berlin, 1962, amelynek magyar fejezetét a Pedagógiai Tudományos Intézetének munkatársai írták.

A jelentős forrásértékü kiadványban valamennyi szovjet befolyás alatt álló szocialista-kommunista ország oktatásügyét bemutatják az intézményes neveléstudomány képviselői: a Bolgár Tudományos Akadémia Pedagógiai Intézete (Szófia), a Csehszlovák Tudományos Akadémia Jan Amos Komensky Pedagógiai Intézete (Prága), a Német Központi Pedagógiai Intézet (Berlin), az OSZSZSZK Neveléstudományi Akadémiája (Moszkva), a Pedagógiai Intézet (Varsó), a Pedagógiai Tudományok Intézete (Bukarest) és a Pedagógiai Tudományos Intézet (Budapest) munkatársai. A kollektívák vezetői: Ábent Ferenc (Budapest), Arszenyev, Alekszandr Mihajlovics (Moszkva), 
Csakarov, Najden (Szófia). Dyma, Mojmír (Prága), Gabream, Iosif I. (Bukarest), Goncsarov, Nyikolaj Kirillovics (Moszkva), Günther, Karl-Heinz (Berlin), Kozjar, Jaroslav (Prága), Pechersky, Mieczyslaw (Varsó) és Stojan, Stanciu (Bukarest)

${ }^{10}$ A 'demokratikus' szó használata a társadalmi egyelőséget is jelentheti, ugyanazt, aminek kifejezésére korábban a 'szocialista' fogalom szolgált. A szük társadalmi elit középiskolai monopóliumának a megdöntését az osztályharc részének tekintették, amit nem is neveztek demokratikusnak.

${ }^{11}$ Azokra gondolt, ,,akiknek idegenből visszatért elvtársai adták át a künn szerzett ideológiai tudást, s akiket ők részesítettek pártvezetésre és vezetésre vonatkozó kiképzésre" (Bassola, 1998, 363. o.).

${ }^{12}$ Bassola nézőpontjából egyforma minden kommunista, vagy feléjük forduló szociáldemokrata. Nagy különbség van azonban közöttük is, elég, ha a magyarországiak közül Kemény Ferencre és Ágoston Györgyre, vagy a Szovjetunióból érkezettek közül Mérei Ferencre és Andics Erzsébetre gondolunk. Arról nem is szólva, hogy 1948 után a politikai üldözés célpontjává a hazai baloldal képviselői váltak, például Rajk és Szakasits.

${ }^{13}$ A néptanítók szervezetei már 1896 óta követelték az egyenrangúságot a gimnáziumi tanársággal. Ez volt az egyik motívuma a tanítóképzés felsőfokú szintre emelésének, egyúttal a vele járó jövedelem elérésének útja. Ehhez a politikához kapcsolódott a 8 osztályos népiskola felállításának követelése 1910-ben (Donáth, 2015, 256-259. o.; Kelemen, 1993, 24. o.).

${ }^{14}$ A néptanítók radikalizmusára Magyarországon Gömbös politikája és később a nyilas mozgalom is épített.

${ }^{15}$ E politikusi szavak világossá teszik a pedagógiai-szakmai koncepciók politikai jellegét és értékét. 1945-ben a tanítóság évtizedes követelése teljesült: létrejött és a tanítóké lett az egységes nyolc osztályos általános iskola, és megszünt a középfokú tanítóképzés egy időre. A felsőfokú Pedagógiai Főiskolán az alsó és a felső tagozati oktatásra készítették a tanítókat (Ladányi, 1989, 36. o.). Végül is, amint a kapitalizmus elleni harc győzelemmel zárult, a tanítóknak tett politikai ígéretekből nem lett semmi, akárcsak az önálló gazdálkodásból a földosztás után Magyarországon. Amit adtak a tanítóságnak, el is vették 1949ben: a felsőfokú képzést és az általános iskola felső tagozatát. Visszaállították a középfokú tanítóképzést, a Pedagógiai Főiskolákon csak a felső tagozat tanárait képezték. Szaktanítóként a felső tagozaton dolgozni a szaktanfolyam sikeres elvégzését követően lehetett. A tanítók munkaterhei továbbra is nagyobbak, jövedelmük viszont alacsonyabb lett, mint a Pedagógusképzőt végzett kollégáké. A középfokon dolgozó tanárok hozzájuk képest relatív előnye noha csökkent, de továbbra is fennmaradt. Ezek után a mindkettőjükkel szembeni tanítói ressentiment érzése állandósult.

${ }^{16}$ Tudható, hogy a szovjet befolyás erős volt az negyvenes és ötvenes években. Azt nem tudjuk, hogy ebben mennyi volt utasítás teljesítése, és mennyi az eszme-követő magatartás. Az azonban ismert, hogy az SZKP vezetőinek politikáját szorosan követte a szocialista országok többsége (ld. az 1958-ban kezdődő hruscsovi reformról: Faragó, 1959b és hatásáról: pl. Jóború, 1951; Sáska, 1981; a korábbi időszakokról: Sáska, 2009; Kalmár, 2014).

${ }^{17}$ Kontextus kedvéért idézem a kihagyott mondatot: „Az egyes iskolafokozatok tanterveinek ennek következtében lépcsőzetesen egymásra kell épülniük." A miniszterhelyettes a tantervi szabályozás lényegére mutatott rá.

${ }^{18}$ Itt jegyzem meg, hogy a 'zsákutcás' képzés megszüntetésének politikai ígérete azonos az érettségi és a felsőfokú végzettség megszerzésének és ezzel a társadalmi felemelkedés lehetőségének a felcsillantásával.

${ }^{19}$ Az UNESCO 1956-ban tartott konferenciája példaként egyedül csak Norvégiát tudja felhozni, ahol „több mint 30 éve [...] a 7-14 éves gyerekek számára kivétel nélkül bevezették az egységes iskolát" (Faragó, 1959a, 31. o.).

${ }^{20} \mathrm{Az}$ elemzett államok köre: Német Szövetségi Köztársaság, Belgium, Franciaország, Olaszország, Egyesült Királyság, Svédország, Svájc, Amerikai Egyesült Államok. A kiadvány forrása a technique, art, science címü folyóirat 1966. március-áprilisi, 197-198. száma.

${ }^{21}$ Történelmi értelemben a 113 ??? nem 133? napot megélt magyar Tanácsköztársaság 1919. március 27-én megjelent rendeletében államosította az iskolákat és rendelte el a nyolcosztályos, kötelező, ingyenes népiskolát (Dancs, 1977). A rendelet mögött álló koncepció koherenciája szakmai tekintetben kiemelendö.

${ }^{22}$ Az ENSZ Emberi jogok egyetemes nyilatkozata elfogadva és kihirdetve az ENSZ Közgyülésének 217 A (III) határozata alapján, 1948. december 10-26. cikke a szákutcás képzés - puhán megfogalmazott: ui. az 'érdem' kultúrafüggő, tehát politikai fogalom - tilalmát mondja ki: „(1) Mindenkinek joga van az oktatáshoz. Az oktatásnak legalább elemi és alapfokon ingyenesnek kell lennie. Az elemi oktatás kötelezö. A müszaki és szakoktatást általánossá kell tenni, és a felsőfokú oktatás is legyen érdeme alapján mindenki számára egyaránt hozzáférhető"

${ }^{23}$ A Kisgazdapárt és a szociáldemokraták 1942-től szorosan együttműködtek. Az 1943. 06. 21-én létrejött Polgári Tagozat az illegális kommunistáknak tette lehetővé a beszivárgást (http://lexikon.katolikus. $\mathrm{hu} / \mathrm{K} /$ kisgazdap $\% \mathrm{C} 3 \% \mathrm{~A} 1$ rtok$\% 20$ Magyarorsz $\% \mathrm{C} 3$ \%A1gon.html). Ortutay a Kisgazdapárt balszárnyának egyik vezető személyisége, baráti körével együtt a róla elnevezett „O”-csoport tagja. 1945 szeptemberétöl a néprajz egyetemi tanára, majd akadémiai levelező tag. 1946. március 7-én egyik aláírója az FKGP balszárnya nyilatkozatának, amely támogatta a Baloldali Blokk követeléseit. 1946. május elejétől - a Magyar Kommunista Párt kívánságára - tagja lett az FKGP Politikai Bizottságának. Baloldali magatartá- 
sa miatt 1946 júliusában pártfegyelmit kapott, majd augusztus elején kizárták a politikai bizottságból (http://www.rev.hu/sulinet45/szerviz/kislex/biograf/ ortutay_g.htm). Ortutay 1945. március 7.-től lett titkos kommunista párttag (Donáth, 2008, 84. o.), nem valószínü, hogy 1943-ban az oktatási terv készítésében kommunista instrukciót kapott volna.

${ }^{24}$ Lehet, hogy technikai értelemben a kisgazdapárti koncepció volt az 1945-ös általános iskola tervének kiindulópontja, a feltevés természetesen igazolandó.

${ }^{25}$ Amennyiben erősebb bizonyítékokkal igazolható a sejtés, akkor ezek szerint az 1948 utáni, minden országra kiterjedő, birodalmi egységesítő szovjet politika első kísérleteinek egyikével állunk szembe.

${ }^{26}$ Pilsutzky 1932-es reformja megszüntette a porosz eredetű, a magyarországihoz hasonló szerkezetü oktatási rendszert, egységes hat osztályos népiskolát teremtett, ahonnan a négy évfolyamos gimnáziumba lehetett tovább tanulni. A reform előtti 8 osztályos gimnázium első felét nevezték 1932 után gimnáziumnak, amelynek elvégzése azonban felsőfokú továbbtanulásra nem jogosított. A 6+4 rendszerü képzés befejezés után két éves líceumi tanulmányok után lehetett felsőfokú képzésben részt venni. A német megszállás előtt $6+4+2$ rendszer volt kiépülőben, amelyben - úgy tủnik - nem volt „zsákutcás” típus, azonban hierarchikus felépítésű volt és erősen szelektív logikán alapult.

${ }^{27}$ Meglehet, hogy a magyar $8+4$ rendszer fennmaradása összefügg a 8 osztályos népiskola, illetve az egységes és általános nyolc osztályos általános iskola 1945-ös létrehozásával.

${ }^{28} \mathrm{Az}$ oktatás tartalma fölötti totális állami kontroll első lépéseinek egyike volt az 1946-ban meginduló állami tankönyvkiadás, amit a pedagógiai elit a szakmaiság piacgazdaság felett aratott győzelmének és a társadalmi egyenlőség megteremtése feltételének tekintett (Kiss, 1946). Az tudható, hogy a középosztály közömbösen fogadta a folyamatos államosítást, a nem-magyar gyár- és üzemtulajdonosok sorsát nem követték, a következményeit pedig nem látták (Szabó, 2014).

${ }^{29}$ A néptanítók szervezetei már 1910-ben követelték a 8 osztályos népiskola felállítását (Kelemen, 1993, 24. o.).

${ }^{30}$ 1940. évi XX. törvénycikk az iskolai kötelezettségről és a nyolcosztályos népiskoláról.

${ }^{31}$ A helyzet 1940-hez képest csak rosszabb lett 1945 ben. Megbízható adatok hiányában csak annyi mondható, hogy az új iskolatípus érdemi müködtetéséhez a tárgyi és a személyi feltételeknek rosszabbaknak kellett lennie 1945-ben, mint 1940-ben, hiszen mindezek hiányoztak a nyolcosztályos népiskola kiépítéséhez: Tesléry Károly, a VKM népiskolai ügyosztályának vezetője szerint az 1945/46-os tanév végén „167 iskola szünetelt tanítóhiány miatt" (idézi: Knausz, 1994, 9. o.), de nem említi sem a harcok során használhatatlanná vált, valamint katonai (kórház, raktár, laktanya stb.) és politikai célokra (pártház) lefoglalt iskolaépületeket. A Tesléry által közölt szám az 1937/38as tanévben múködő 6899 népiskola töredéke: 2,4 százaléka, vagyis valószínütlenül alacsony az arány. A tanítói hiány nagyságát sem lehet pontosan tudni. Tesléry kimutatása nem is tartalmazza az elhunyt tanítókat, az iskolában dolgozók köre sem lehet teljes (2984 fö). Knausz (1994, 9. o.) becslése szerint a munkából kiesett „legalább” 3336 tanító. Ezek szerint az 1937/38-as tanévben népiskolában tevékenykedő 20149 néptanító 14,8-16,6 százaléka hiányzik. Ez persze alsó becslés. A hiány ennél biztosan nagyobb, de nem tudjuk, mennyivel (KSH, 1938, 265. o.).

32 1951. 15. Tvr. a tankötelezettségről és az általános iskoláról 2. §. (1): „A tankötelezettség a gyermek hatodik életévének betöltését közvetlenül követő szeptember hó 1 . napjával kezdődik és megszakítás nélkül annak a tanévnek a végéig tart, amelyben a gyermek a tizennegyedik életévét betölti."

2. §. (2): „Ha a tanköteles gyermek nyolc év alatt nem végzi el az általános iskola nyolc osztályát, a községi (városi, városi kerületi) tanács végrehajtó bizottsága a szülö kérelmére a gyermek tankötelezettségét [időkorlát nélkül - S. G.] meghosszabbíthatja.’”

1940. évi XX. törvénycikk az iskolai kötelezettségről és a nyolcosztályos népiskoláról 4. §. (3): „Ha a tanuló a nyolc tanévre terjedő mindennapi népiskolai tanítás ideje alatt a tantervben meghatározott ismereteket és készségeket nem sajátította el, a királyi tanfelügyelő a népiskola látogatásának kötelezettségét az iskola helyi hatóságának (gondnokságának, iskolaszékének), a tanító (tanítótestület) jelentése alapján tett javaslatára egy évvel meghosszabbíthatja.'

${ }^{33}$ 1950-ben az általános iskolák közel nyolcvan százalékában a tanulók életkori és évfolyam szerinti bontás nélkül, egy tanteremben, egy tanító irányításával tanulnak (Forray R., 1976, 25. o.). Nekik még a rossz minőségü felső tagozati - alsó gimnáziumi - oktatásban sem lehetett részük. Az általános iskolai felső tagozati szaktárgyi órák közel egyötödödét más szakra képesített tanárok látták el. A matematika-fizika órák 38, a magyar-történelem órák 28 százalékát nem ezekre képzett tanárok látták el (Erdészné, 1957, 693. o.). Az 1951. évi 15. sz., a tankötelezettségről és az általános iskoláról szóló törvényerejü rendelet 14. §. (2) pontja szerint a közoktatásügyi miniszter átmenetileg engedélyt adhat a szaktanítói vagy tanári képesítéssel nem rendelkezők „müködésére”. Erre gyakorta sor kerülhetett.

${ }^{34} \mathrm{Nem}$ volt, aki cáfolhatott volna: a VKM vezetői és tovább nem szolgáló tisztviselői, valamint az érintett kis számú gyerek szülei és a tanítók gyenge szava nem is kapott nyilvánosságot.

${ }^{35}$ A szovjet csapatokat követték Budapest végcél felé a debreceni Ideiglenes kormány körül megjelent, mértékeltnek tekinthető nemzeti-fajvédő, müvelt pedagógusok is, mint például a szociáldemokratává vált Simon László, a VKM államtitkára 1945-ben, aki a harmincas években még a debreceni zsidóve- 
rő Árpád Bajtársi Egyesület alelnöke. Kovács Máté az Árpád Bajtársi Egyesületben a bölcsészkari Turul szervezet vezére volt az 1928. októberi zsidóellenes atrocitások idején, de az 1930-as évek közepén már francia lektorként és tanársegédként dolgozott a karon (Kerepeszki, 2004, 149., 155., 163. o.). Itt jegyzem meg, hogy az 1945 után kiadott lexikonok életrajzi adatainak szerkesztési elvei közé tartozik az elhallgatás is.

${ }^{36}$ Kovács Máté világosan látja, hogy a szelekció alapja tudás és az ismeret. Az idézetben kipontozott részben arról ír, hogy a ,tananyag és a módszer tekintetében [...] az egyoldalú értelemi, majd később a testi nevelést szolgálja" (Kovács, 1945, 107. o.). Megjegyzem, hogy az 'egyoldalú értelmi nevelés" bírálata közös az erős antiintellektuális reformpedagógiai gondolattal. A bírálat politikai éle a gimnázium kultúrája és klientúrája ellen vág.

${ }^{37} \mathrm{Az}$ eredeti szöveget cenzúrázva jelentették meg 1983-ban „a kevésbé jelentős kérdésre vonatkozó részeket" elhagyták (Szelle, 1983, 175. o.), a szerkesztők pedig elmaszatolják jegyzetükben a 'magyar lélek' eredeti jelentését. Szerintük mindez pusztán pszichikumot jelent (Szelle, 1983, 216. o.).

${ }^{38}$ Boda István (Máramarossziget, 1894-1979): A budapesti tudományegyetemen magyar-francia szakos középiskolai tanári oklevelet (1917), majd bölcsészdoktori oklevelet szerzett (1929). Egyetemi magántanár a szegedi tudományegyetemen (1932). Középiskolai tanár Fiumében (1917-20), majd Budapesten a Kereskedelmi Akadémián (1920-39) tanított. A kassai Kereskedelmi Főiskola francia-olasz szakos tanára és a lélektani laboratórium vezetője (1939-44), majd a kolozsvári egyetemen a neveléstan tanszék vezetője (1944). Ismét Budapesten a Kereskedelmi Főiskola tanára (1945-50). 56 évesen nyugdíjaztatták, a közéletből kiszorították.

Jelentősen hozzájárult a Magyar Pedagógiai Társaság megalapításához (1928), amelynek ügyvezető titkára (1928-36), alelnöke (1936-38), ügyvezető társelnöke (1938-41), majd ügyvezető elnöke (1942-44) volt. Kutatásokat végzett a személyiség-, valamint a neveléslélektan területén. Pszichológiát oktatott a Müszaki Egyetem Közgazdasági Karán. Tanulmányainak jelentős része az általa is szerkesztett Magyar Pszichológiai Szemlében jelent meg. Főbb művei: Lélektan és karakterológia (1933); A személyiség szerkezete és kísérleti vizsgálata (1939); A Magyar Pszichológiai Társaság Elaboratuma... (társszerzővel, 1932) (http://mek.oszk.hu/00300/00355/html/). A neve a hetvenes években kiadott Pedagógiai lexikonban nem szerepel.

${ }^{39}$ Az idézet a következőképpen folytatódik: „Csak egyetlen érdekes ily különbséget említve: a magyar származású ügyvédek elvi és tárgyi alapú, az elv, a törvény sérelmétől kiváltott felháborodásával szemben a zsidó származású ügyvédekben szinte kizárólag csak a személyi gyöngeségek, emberi hitványságok miatti morális felháborodásokat találjuk: náluk az elvet magát ért sérelem, a törvény objektív szellemé- nek sérelme szinte soha nem váltja ki a felháborodás kitöréseit" (Boda, 1944, 29. o.).

${ }^{40} 1945$ áprilisától az Országos Köznevelési Tanács elnökségi tagja, a középiskolai szakosztály elnöke, a Magyar Népművelők Tudományos Társaságában a Pedagógiai Szakosztály elnöke. 1945 júniusában a Magyar Cserkészszövetség tiszteletbeli elnöke lesz, Sík Sándorral együtt. 1945. október 9-én a VKM rendelete alapján megalakul az Országos Szabadművelődési Tanács, melynek első elnöke szintén Karácsony Sándor. 1945. október 21-én a Magyar Evangéliumi Keresztyén Diákszövetség (MEKDSz) újra elnökévé választja.

1946. augusztus 22-én megalakul a Magyar Cserkészfiúk Szövetsége, amelynek elnöke természetesen Karácsony Sándor. 1946 szeptemberétől a debreceni tudományegyetem Tanárképző és Tanárvizsgáló Bizottságának elnöke. 1946. október 12-én a Magyar Demokratikus Ifjúsági Szövetség (MADISZ) elnökévé választják. 1947-től 1948-ig főszerkesztője a paraszti életforma hagyományainak ápolását végző Új Szántás címü, az Országos Szabadmüvelődési Tanács kiadásában havonként megjelenő folyóiratnak.

${ }^{41}$ A tandíjemelés - szolidaritás ide vagy oda - népszerütlen volt a gyermekeiket a polgári iskolába és a gimnáziumba járató szülők körében. A tandíjak eltörlésének kommunisták általi (1945 utáni) követelését nyilván mindegyik társadalmi réteg örömmel fogadta. Szavazatszerzés szempontjából általában jó taktika a család költségeinek állami átvállalása, illetve ennek ígérete, a hatalommegragadás szempontból pedig közömbös, hogy az országnak a vesztes háborút követően milyen a pénzügyi helyzete.

${ }^{42}$ Emblematikus, hogy a nyolcvanas évek oktatáspolitikai fordulata hozza létre a politikai skála két szélső pontját: a Németh Lászlóról elnevezett nyolc osztályos gimnáziumot (Hoffman Rózsa) és az Alternatív Közgazdasági Politechnikumot (Horn György).

${ }^{43}$ „A népi állam feladata lesz, hogy a közoktatás útján gondoskodjék a meglévő szellemi vezetőrétegnek az alulról jövő vérfrissítés útján történő állandó megújhodásáról. [...] Az államnak kötelessége az, hogy a néptársak körében a legnagyobb gondossággal és pontossággal kiválassza és a köz szolgálatába állítsa a természet által láthatólag a legnagyobb tehetséggel megáldott emberanyagot. [...] Minthogy az ésszerúen berendezett államban arra kell törekedni, hogy minden egyes embert tehetségének megfelelő pozícióba juttassanak, vagyis másként kifejezve, hogy az embereket a tehetségüknek megfelelő munkára képezzék ki, azt kell szem elött tartanunk, hogy tehetséget nem lehet elsajátítani, hanem azzal születni kell, mert az a természet ajándéka, és nem az embernek a megszolgált jutalma." (Hitler, 1939, 644. o.)

${ }^{44}$ Hitler előbbi gondolatait ismétli Hóman Bálint (1942, idézi: Kiss, 1943, 49. o.): „Korunk egyik szomorú jelensége az, hogy a nemzet életében a vezetésre hivatott tehetségek gyakorta elvesznek a közös- 
Sáska Géza: Az egységes és általános iskola megteremtése

ség számára s helyüket erkölcs és tudás tekintetében kisebb értékü elemek foglalják el [...] A közszolgálatban avagy a magángazdasági életben hasznos munkát végző emberek [...] oly vezető szerepre vágynak, aminőnek a betöltésére tehetségük iránya, képességük terjedelme és müveltségük minősége miatt teljességgel alkalmatlanok [...] Másfelől pedig nagyképességü, magasműveltségü, vezetésre hivatott kiváló egyéniségek [...] fosztják meg a nemzeti közösséget szellemiségük gyümölcsétől" (Hóman, 1942, idézi: Kiss, 1943, 49.o). Ebben az ideológiai térben értelmezte Kiss Árpád 1940-ben a majdani vezetők nevelésének és kiválasztásának pedagógiai problematikáját (Kiss, 1940).

${ }^{45}$ Valószínüleg fogalmuk sem volt azoknak, akik az 1993-ban elfogadott Közoktatási törvényben felállították az Országos Köznevelési Tanácsot, hogy ezzel a névvel a magyar fajvédö/szocialista örökséget is a nyakukba kapták. Az emlékezettörténet szerint az OKNT 1945 és 1948 közötti demokratikus képe maradt fenn, amely nem tartalmazta a politikai-ideológiai átmenet jó néhány szereplőjének háború előtti szerepét, s akiket a Magyar Kommunista Párt útitársként kezelt.

${ }^{46}$ Vélhetően Kovács Máté szövegezése. Meglehetősen nagy a tartalmi átfedés Kovács (1945) kézirata és az OKNT utasítása között.

${ }^{47}$ A tanárképzés területére most nem léphetek, közelebbröl ld. Donáth, 2008.

${ }^{48}$ Ismereteim szerint a fajvédő, nemzetnevelő oldalról ez az első 1945 utáni hivatalos pedológiát támogató dokumentum. Megvizsgálandó, hogy az 1950-ben indított pedológia elleni kampány célpontjai között szerepeltek-e jobboldalról érkezett gyermekbarátok.

${ }^{49}$ Ld. a 3820/1945. ME. r. a német lakosság kategorizálásáról és e csoportok elleni intézkedésekről (júl. 1.), valamint 12.330/1945. ME. r. a németek kitelepítéséről (dec. 29.)
${ }^{50}$ A világnézeti értékháttér ki nem fejtése, a politikai célok eltitkolása adja meg a szakmai alap kereteit.

${ }^{51}$ Az idézetben szereplő szociáldemokrata Faragó László nem azonos a hasonló nevü pedagógussal és szakpolitikussal, aki a Magyar Kommunista Párt tagja volt.

${ }^{52}$ A Magyar Radikális Párt (Csécsy Imre, Zsolt Béla) hetilapja 1945 és 1949 között.

${ }^{53}$ A politikai jellegű Országos Köznevelési Tanács helyébe a szakmai Országos Neveléstudományi Intézet lépett, amelynek vezetője Mérei Ferenc lett, a Didaktikai osztály élére Kiss Árpád került.

${ }^{54}$ Többek között Báthory Zoltán (2007) szerint Kiss Árpád (1907-1979) a hazai progresszív pedagógia egyik jeles képviselője.

${ }^{55}$ Karácsony nyugdíját később meg is vonták, vélhetően másokét is, az osztályharc fokozódásának éveiben.

${ }^{56}$ Többek között Ágoston György, Nagy Sándor, Szarka József.

${ }^{57}$ Az erkölcsi nevelés Szarka értelmezésében azonos a kommunista világnézet kialakításával.

${ }^{58}$ A jobboldali nacionalista, nemzeti fajvédők, valamint a 'hazai' és Nyugat-orientált kommunisták diszkreditálása után a 'nemzeti' szó használatát felváltotta a 'hazafias' kifejezés, amelyböl ki lehetett zárni mint ellenséget az előbbi két csoportba soroltakat.

${ }^{59}$ A Központi Vezetőség 1950. március 29-i határozata nem szerepelt az Ágoston György és tanítványa, Gácser József lektorálta, 1980-ban kiadott közoktatás- és művelődéspolitikai dokumentum-gyüjteményben (Koncz és Szabó, 1980). Tehát a sztálinista-szocialista oktatáspolitika már nem érvényes 1980-ban, erről nem is kell tudniuk a tanárképzésben részt vevő egyetemi és föiskolai hallgatóknak.

\section{Irodalomjegyzék}

Ábent Ferenc és a Pedagógiai Tudományos Intézet munkaközössége (1965): A Magyar Népköztársaság közoktatásügye: In: Ábent Ferenc (szerk.): A közoktatásügy Európa szocialista országaiban. Tankönyvkiadó, Budapest. (Az eredeti kiadás: Das Schulwesen in der sozialistichen Lander In Europa. [1962] Volk and Wissen Volkgseigener Verlag, Berlin).

Applebaum, A. (2014): Vasfüggöny. Kelet-Európa megtörése 1944-1956. Európa Könyvkiadó, Budapest.

Arszenyev, A. M. (1965): A szocialista és kommunista nevelés alapvonásai. In: Ábent Ferenc (szerk.): A közoktatásügy Európa szocialista országaiban. Tankönyvkiadó, Budapest. 11-46.
Ballai Károly (1929): A magyar gyermek. Eredeti mérések és lélektani adatok alapján. Magyar Gyermektanulmányi Társaság, Budapest.

Balogh Sándor (1980, szerk.): Földet, köztársaságot, állami iskolát! Viták a Magyar parlamentben 1944-1948. Gondolat, Budapest.

Bassola Zoltán (1998): Ki voltam... Egy kultuszminisztériumi államtitkár vallomásai. Országos Pedagógiai Könyvtár és Múzeum, Budapest.

Báthory Zoltán (2007): Kiss Árpád társadalompedagógiája. Neveléstörténet, 1-2. sz.

Boda István (1944): A magyar lélek alapformái és természetes fejlődéslehetőségei. In: Kiss Árpád és Kovács Máté (szerk.): Magyarságtudomány és nem- 
zetnevelés. Debreceni könyvek, Debrecen. 21-45. h t t p :// m tdaportal.extra.hu/books / magyarsagtudomany_es_nemzetneveles.pdf

Braham, R. L. (2015): Magyarország: hadjárat a holokauszt történelmi emlékezete ellen. In: uő és Kovács András (2015, szerk.): A holokauszt Magyarországon hetven év múltán. Múlt és Jövő Alapítvány. 229-278.

Csakarov, N., Vasziljev, H., Hruszszanov, G., Janev, Sz. és Pavlov, I. (1965): A Bolgár Népköztársaság közoktatásügye. In: Ábent Ferenc (szerk.): A közoktatásügy Európa szocialista országaiban. Tankönyvkiadó, Budapest. 47-110.

Csanády Sándor (1940): A Kitünőek Iskolája. Protestáns Tanügyi Szemle, 14. 9. sz. 237-241.

Dancs Istvánné (1979, szerk.): Dokumentumok a magyar közoktatás reformjáról / 1945-1948. Kossuth Könyvkiadó, Budapest.

Donáth Péter (2008): Oktatáspolitika és tanitóképzés Magyarországon 1945-1960. Trezor Kiadó, Budapest.

Donáth Péter (2015): Tanítói, tanári viták. A magyarországi tanítók társadalmi küldetéséröl, helyzetük javításáról, a tanítóképzés korszerüsítéséről, felsőfokúvá tételéről 1890-1905. In: Filozófia - müvelödés - történet 2015. (A Budapesti Tanítóképző Főiskola Tudományos Közleményei címü kiadványsorozat folytatása) 256-259.

Dyma, M. és Kozjar, J. (1965): A Csehszlovák Szocialista Köztársaság közoktatásügye. In: Ábent Ferenc (szerk.): A közoktatásügy Európa szocialista országaiban. Tankönyvkiadó, Budapest. 111-182.

Eckhardt Sándor (1941, szerk.): Úr és paraszt a magyar élet egységében. Budapesti Kir. Magyar Pázmány Péter Tudományegyetem Bölcsészeti Karának Magyarságtudományi Intézete, Budapest. http:// mtdaportal.extra.hu/books/eckhardt_sandor_ur_es paraszt.pdf

Erdész Tiborné (1957): A közoktatás helyzete. Statisztikai Szemle, 35. 8-9. sz. 689-704.

Faragó László és Kiss Árpád (1949): Az új nevelés kérdései. Egyetemi Nyomda.

Faragó László (1959 a, szerk.): Az iskolareform és a nevelés problémái a kapitalista országokban. Pedagógiai Tudományos Intézet, Budapest.

Faragó László (1959b, szerk.): A nevelés és iskolarendszer problémái néhány szocialista országban. Pedagógiai Tudományos Intézet, Budapest.

Forray R. Katalin (1976): Az iskolakörzetesités társadalmi hatásai. Egyetemi doktori értekezés. Szeged. http://mek.oszk.hu/11200/11223/11223.pdf

Földes Ferenc (1941): Munkásság és parasztság helyzete Magyarországon. Cserépfalvi.

Georgeoff, P. J. (1977): The Educational System of Bulgaria Education around the World Office of Edu- cation (TEEN). Washington, D. C. http://eric.ed. gov/?id=ED 156600

Golnhofer Erzsébet (2004): Hazai pedagógiai nézetek 1945-1949. Iskolakultúra, Pécs.

Hitler, A. (1939): Mein Kampf. Reynal \& Hitchcock, New York.

Illés Lajosné (1967, szerk.): Nyolc tőkésállam közoktatási rendszere. Tankönyvkiadó Budapest.

Horváth M. (1978): Közoktatás-politika és általános iskola. Akadémiai Kiadó, Budapest.

Jóború Magda (1962): Élet és iskola. A modern köznevelés történelmi és társadalmi háttere. Gondolat Kiadó, Budapest.

Jóború Magda (1972): A köznevelés a Horthy-korszakban. Kossuth Könyvkiadó - Tankönyvkiadó, Budapest.

Kalmár M. (2014): Történelmi galaxisok vonzásában. Magyarország és a Szovjetrendszer 1945-1990. Osiris Kiadó, Budapest.

Kardos József (2007): Iskola a politika sodrásában 1945-1993. Gondolat-Infonia, Budapest.

Kelemen Elemér (1993): A magyar pedagógusmozgalmak és -szakszervezetek vázlatos története. In: „Lázad hát már az élet alágyürtje, a tanitó...?” 75 éves a Pedagógusok Szakszervezete. Pedagógusok Szakszervezete, h.n. 7-48.

Kerepeszki Róbert (2004): A Debreceni Egyetem Bölcsészettudományi Karának története, 1912-1949. In: Papp Klára (szerk): A Debreceni Egyetem Bölcsészettudományi Karának története. Debreceni Egyetem BZK, Debrecen.

Kiss Árpád (1940): A,,vezetők” nevelése és kiválasztása. Protestáns Tanügyi Szemle, 14. 7. sz. 165-173.

Kiss Árpád (1943): Mai magyar nevelés. Debreceni könyvek, Debrecen.

Kiss Árpád (1944): Nevelés magyarul Európában. In: Kiss Árpád és Kovács Máté (szerk.): Magyarságtudomány és nemzetnevelés. Debreceni könyvek, Debrecen. 45-63. http://mtdaportal.extra.hu/books/ magyarsagtudomany_es_nemzetneveles.pdf

Kiss Árpád (1946): A tankönyv. Köznevelés, 22. sz. $1-3$.

Kiss Árpád (1947): Az általános iskola és középiskola. Köznevelés, 6. sz. 102-106.

Knausz Imre (1986): A magyar ,pedológia” pere 1948-1950. Pedagógiai Szemle, 36. 11. sz. 1087 1102.

Knausz Imre (1994): A közoktatás Magyarországon 1945-1956. Kandidátusi disszertáció. http://mek. oszk.hu/10000/10080/10080.pdf

Koncz J. és Szabó G. M. (1980): Közoktatás- és müvelödéspolitika. Dokumentumgyüjtemény. Egye- 
Sáska Géza: Az egységes és általános iskola megteremtése

temek és tanárképző főiskolák egységes jegyzet. Kézirat. Tankönyvkiadó, Budapest.

Kovács Máté (1945): A magyar irodalom szerepe korszerü köznevelésünkben. In: Sík Sándor (1945): Demokrácia és Köznevelés. Országos Köznevelési Tanács, Budapest. 107-114.

Kovács Máté (1983): A magyar köznevelés korszerü kifejlesztése. In: Szelle Béla (szerk.): Kovács Máté emlékkönyv. Magyar Könyvtárosok Egyesülete, Budapest. 175-216.

Központi Statisztikai Hivatal (1938): Magyar Statisztikai Évkönyv 1938. Központi Statisztikai Hivatal, Budapest.

Ladányi Andor (1989): Mennyiségi fejlődés és strukturális változások: a felsőoktatás útja a felszabadulás után. Tankönyvkiadó - Oktatáskutató Intézet, Budapest.

Magyar Dolgozók Pártja Központi Vezetősége által határozata a Vallás- és Közoktatásügyi Minisztérium munkájával kapcsolatos kérdésekről. (1951) In: Magyar Dolgozók Pártja Központi Vezetöségének, Politikai Bizottságának és Szervezö Bizottságának fontosabb határozatai. Szikra, Budapest. 175-181.

Martinkó József (2006): Fejezetek a magyar tehetséggondozás történetéböl. Neveléstörténet, 3-4. sz. http://www.kodolanyi.hu/nevelestortenet/?act= menu_tart\&rovat_mod=archiv\&eid $=34 \&$ rid $=1 \&$ id $=220$

Nagy László (1930): A tehetség kifejlődésének fő tényezői. In: Tehetség problémák. A Magyar Gyermektanulmányi és Gyakorlati Lélektani Társaság Pszichológiai Szemináriumában előadták: Balassa László, Hermann Imre stb. A Magyar Gyermektanulmányi és Gyakorlati Lélektani Társaság, Budapest. 81-82.

Nagy Sándor (1976, főszerk.): Pedagógiai lexikon. Első kötet A-F. Akadémiai Kiadó, Budapest.

Németh András, Bíró Zsuzsa Hanna és Garai Imre (2015): Neveléstudomány és tudományos elit a 20. század második felében. Gondolat Kiadó, Budapest.

Németh László (1945): A tanügy rendezése. Sarló, Budapest.

Nemes Dezső (1960): Magyarország felszabadulása. Kossuth Könyvkiadó, Budapest.

Ozorai Frigyes és Bálint Antal (1927, szerk.): Tehetségvédelem és pályaválasztás. Az 1926. évi február hó 2-án és 3-én tartott országos kongresszus naplója, a tehetséges ifjak második kiállitásának leirása és kapcsolatos mozgalmak ismertetése. Magyar Gyermektanulmányi és Gyakorlati Lélektani Társaság, Budapest.

Papp István (2012): A magyar népi mozgalom története - 1920-1990. Jaffa Kiadó.

Pecherski, M. (1965): A Lengyel Népköztársaság közoktatásügye. In: Ábent Ferenc (szerk.): A közokta- tásügy Európa szocialista országaiban. Tankönyvkiadó, Budapest. 183-256.

Pornói Imre (1995): Az 1920-as évek népoktatása és a nyolcosztályos népiskola Magyarországon. Magyar Pedagógia, 95. 3-4. sz. 315-331.

Pornói Rita (2011): A tehetségmentés szerepe a Horthy-rendszer kultúrpolitikájában. Iskolakultúra, 21. 6-7. sz. 123-133

Pukánszky Béla és Németh András (1996): Neveléstörténet. Nemzeti Tankönyvkiadó Rt.

Sáska Géza (1981): Egy döntéssorozat kényszerpályája. Mozgó Világ, 12. sz. 116-124.

Sáska Géza (1988): Az iskolarendszerű felnőttoktatás magyarországi történetének vázlata. Magyar Pedagógia, 88. 1. sz. 373-391.

Sáska Géza (2001): „Jó, hogy vége a nyolcvanas éveknek, és nem jön újra el". Iskolakultúra, 11. 2. sz. 45-62.

Sáska G. (2002-3): The Age of Autonomy. European Education, 34. 4. sz. 34-56. DOI: 10.2753/eue10564934340434

Sáska Géza (2004): A társadalmi egyenlőség antikapitalista és demokrácia ellenes képzete a XX. századi pedagógiai ideológiákban. 1. rész. Magyar Pedagógia, 104. 4. sz. 471-499.

Sáska Géza (2005): A társadalmi egyenlőség antikapitalista és demokrácia ellenes képzete a XX. századi pedagógiai ideológiákban. 2. rész. Magyar Pedagógia, 105. 1. sz. 83-99.

Sáska Géza (2006): A társadalmi egyenlőség megteremtésének kísérlete az ötvenes évek felsőoktatásában. Educatio, 15. 3. sz. 593-608.

Sáska Géza (2011): Új társadalomhoz új embert és új pedagógiát! A XX. századi egyenlöségpárti és antikapitalista pedagógiákról. Gondolat Kiadó, Budapest.

Sáska G. (2009): The Emergence of „real” Socialist Pedagogy. In: Hopfner, J., Németh, A. és Szabolcs, É. (szerk.): Kindheit - Schule Erziehungswissenschaft in Mitteleuropa 1948-2008. Peter Lang, Franfurt am Main. 201-209.

Sáska Géza (2015): A neveléstudományi elit viszonya a politikai marxizmushoz az ötvenes években. In: Németh András, Bíró Zsuzsa Hanna és Garai Imre (szerk.): Neveléstudomány és tudományos elit a 20. század második felében. Gondolat Kiadó, Budapest. 177212.

Sík Sándor (1945, szerk.): Demokrácia és Köznevelés. Országos Köznevelési Tanács, Budapest.

Simon Gyula (1970): Felszabadult nevelésügyünk huszonöt évéről. Pedagógiai Szemle, 4. sz. = uaz. In: Horváth Márton és Zibolen Endre (1975, szerk.): 30 év neveléstudomány és müvelödéspolitika. Magyar Pedagógiai Társaság, Budapest. 
Szabó Miklós (1995): Múmiák öröksége. Politikai és történeti esszék. Új Mandátum Könyvkiadó.

Szabó Miklós (2014): A jó kommunista együtt ingadozik a párttal 1983-2003. Elöadások a kommunista pártok történetéröl és a fekete-piros-fehér-zöld szinre festett sztálinizmusról. JATEPRESS.

Szabolcs Éva (2006, szerk.): Pedagógia és politika a XX. század második felében Magyarországon. Eötvös József Kiadó, Budapest.

Standeisky Éva (2007): Antiszemitizmusok. Argumentum.

Stoian, S. és Gabrea, I. (1965): A Román Népköztársaság közoktatásügye. In: Ábent Ferenc (szerk.): $A$ közoktatásügy Európa szocialista országaiban. Tankönyvkiadó, Budapest. 399-460.

Szarka József (1961): Az erkölcsi nevelés elméletének fejlődése. In: Dancs Istvánné és Simon Gyula (szerk.): Tanulmányok a magyar népi demokrácia neveléstörténetéböl. I. Pedagógiai Tudományos Intézet, Budapest. 7-67.

Szombatfalvy György (1939): A mélymagyarság problémája. Társadalomtudomány, 19. 1-3 sz. 104108.

Szombatfalvy György (1940): A zsidótörvény társadalmi mérlege. Társadalomtudomány, 20. 1. sz. 75-82.

Szombatfalvy György (1941a): Tehetségmentés a falusi népiskolában. Néptanitók Lapja, 1. sz.
Szombatfalvy György (1941b): A társadalmi vezetők és a gimnázium. Társadalomtudomány, 21. 3 sz. 321.

Törvény az iskola és az élet kapcsolatának megszilárdításáról és a Szovjetunió közoktatási rendszerének továbbfejlesztéséröl. Pravda, 1958. december 25. = In: Faragó László (1959b, szerk.): A nevelés és iskolarendszer problémái néhány szocialista országban. Pedagógiai Tudományos Intézet, Budapest.

Ujváry Gábor (2016): Történettudomány vagy törvényszék? Még egyszer a Hóman-perröl. Rubikon, 2. sz. 52-65.

Ungváry Krisztián (2016): Hóman Bálint Népbírósági pere. BBC History, 6. 1. sz.

Vass Henrik és Ságvári Ágnes (1973a, szerk.): Az MSZMP Központi Bizottsága Elméleti Munkaközösségének állásfoglalása a „népi” írókról. In: A Magyar Szocialista Munkáspárt határozatai és dokumentumai 1956-1962. 2. kiadás. Kossuth, Budapest. 210-235.

Vass Henrik és Ságvári Ágnes (1973b, szerk.): Az MSZMP Ideiglenes Központi Bizottságának 1957. februári határozata az időszerü kérdésekről és feladatokról, 1957. február 26. In: A magyar Szocialista Munkáspárt határozatai és dokumentumai 1956-1962. 2. kiadás, Kossuth, Budapest.

Veres Péter (1945): Demokrácia és nevelés: In: Sík Sándor (szerk.): Demokrácia és Köznevelés. Országos Köznevelési Tanács, Budapest. 7-21. 